REVISTA ANDALUZA DE ANTROPOLOGÍA.

NÚMERO 9: LA REPRESENTACIÓN DE LAS CULTURAS EN LA MUSEOLOGÍA ANTROPOLÓGICA DEL ESTADO ESPAÑOL

SEPTIEMBRE DE 2015

ISSN 2174-6796

[pp. 16-51]

http://dx.doi.org/10.12795/RAA.2015.i09.02

Recibido: 12/05/2015

Aceptado: 06/08/2015

\title{
IMÁGENES Y REPRESENTACIONES CULTURALES EN LOS MUSEOS DE GALICIA
}

\author{
Xosé C. Sierra Rodríguez \\ Museo Etnolóxico de Ribadavia (Ourense)
}

\section{Resumen.}

Este artículo plantea el fenómeno de la patrimonialización y de la musealización en Galicia en el marco de la gran transformación operada en el territorio y en la sociedad gallega en los últimos cincuenta años. Se alude a las contradicciones que afloran al relacionar dichos cambios con las representaciones que elaboran los museos, particularmente los etnográficos. Los procesos de urbanización y la desaparición del campesinado no se reflejan en sus musealizaciones, que reproducen una foto fija del mundo agro-campesino como característica de la identidad gallega. La noción de etnografía y sus cuadros socioculturales siguen anclados en relatos superados, lo que convierte a muchos museos “etnográficos” en estampas histórico-arqueológicas ajenas a la visualización de los procesos sociales y de los cambios culturales. También se realiza un breve acercamiento a los museos de artes plásticas como traductores y portadores de repertorios identitarios alternativos o complementarios. Se hace igualmente una revisión sumaria de la reciente historia del museo en Galicia y su tardía incorporación a la normalización cultural del país.

\section{Palabras Clave.}

Campesinado, industrialización, musealización, etnografía, arte, identidad. 


\section{IMAGES AND CULTURAL REPRESENTATIONS IN THE GALICIA'S MUSEUMS}

\section{Abstract.}

This paper addresses the phenomena of patrimonial action and museological promotion which have taken place in Galicia within the frame of the great transformation that both its territory and its society have experimented during the last fifty years, focusing in thecontradictionswhich thosechangesarerelated with theirmuseographicrepresentations, most specifically, the ones that take place in the ethnographic museums. Thus, the processes of urbanization and disappearance of peasantry are not reflected in those museums, which only portray a still picture of the agrarian world as an essential feature of Galician identity. Ethnography, as a notion and a sociocultural frame, is still anchored to a bygone narrative, turning ethnological museums into historical and archaeological depictions, alien to social processes and cultural changes. This paper outlines, as well, a brief approach to the plastic and fine arts museums as translators and bearers of alternative or complementary repertoires. Similarly, the recent history of Galicia's museums is summarized, paying attention to their late assimilation to the country's cultural normalization.

\section{Keywords.}

Peasantry, Industralization, Museological Promotion, Patrimonial Action, Ethnography, Art, Identity.

\section{ACERCAMIENTO SUMARIO AL MAPA DE LA GALICIA CONTEMPORÁNEA}

Galicia deambula por un camino en el que los desajustes y reajustes, los desequilibrios y reequilibrios internos y externos le confieren un perfil propio no sólo con relación a los restantes territorios del Estado, sino también en el concierto cultural europeo. Historiadores, geógrafos, economistas, sociólogos y antropólogos han señalado que los cambios experimentados a la vuelta de 1970 han sido profundos y acelerados. La velocidad adoptada por estas transformaciones justifica la dificultad para asumirlas y la complejidad para explicarlas. Pero fundamentalmente esa velocidad condiciona enormemente la gestión del cambio, su asimilación y la configuración de alternativas que sustituyan un pasado desarticulado por un presente y un porvenir coherentes con el proceso. Transformar una herencia, cuyo inventario de bienes está muy fragmentado y cuya gestión no se somete con facilidad a los imperativos del nuevo marco, no es tarea fácil.

Los especialistas de las disciplinas aludidas coinciden en definir la sociedad gallega del presente como una sociedad desagrarizada, pero que ha llegado a esta situación a través de una génesis cuyo cronómetro no supera el límite de los cincuenta años. Una sociedad 
desagrarizada a un coste muy elevado, ya que en un período tan corto se han invertido los términos de la relación población rural-población urbana. Pero no es sólo la inversión de los porcentajes entre ambos polos lo que conviene señalar, sino, y de manera especial, que el grupo social mayoritario hasta el cambio, el campesinado parcelario, desapareció como construcción social efectiva disuelto en otras tipologías que las relaciones de producción agrarias determinaron. Un campesinado imaginado como estamento social homogéneo que había experimentado muchos otros cambios sucedidos al traspasar con lentitud el umbral de salida de la economía campesina. Un campesinado heterogéneo, con etnoclases internas bien definidas y denominadas por los primeros antropólogos sociales que, a finales del siglo XIX y comienzos del XX (Rodríguez Campos, 1991: 102106; González Reboredo, 1996: 708-709), testimoniaron con presteza que en el agro galaico existían muchos desposeídos, como existían grandes y pequeños propietarios, unos detentadores del dominio directo y otros explotadores del dominio útil de los primeros; estos últimos combinaban el aprovechamiento de sus limitadas propiedades con el trabajo de las tierras de otros, mediante contrato foral -cesión enfitéutica de tierras por varias generaciones- o mediante un sistema de aparcería que los convertía en 'caseiros' de importantes propietarios agrarios (Soutelo, 1998:136ss). La redención foral, formalmente datada en 1926, permitió antes y después de esa fecha a muchos foreros hacerse con la propiedad plena de las tierras de los propietarios, muchos de ellos miembros de la vieja hidalguía rural y en claro declive desde el siglo XIX. Cardesín (1999:133ss) recupera y disecciona esa estructura social y nos explica cómo el sistema liberal de la Restauración articula unos poderes locales y una organización judicial, paralelos a la formación de un mercado estatal y mundial al que asoma el mundo agrario gallego y su peculiar, en continua mudanza, sociedad campesina. Posteriormente, después del Plan de Estabilización de 1959 se percibe una disolución gradual de los marcos económicos y sociales configurados alrededor de la aldea en un proceso, todavía inconcluso, en lo relativo a sus consecuencias en las esferas económica, social, demográfica y simbólica. El campesinado no presentaba ya en el entorno de 1960 la heterogeneidad de antaño y la dictadura lo rebautiza y confirma como productor agrícola, propulsando las transformaciones que se suceden en su organización sociolaboral, en sus posibilidades de innovación técnica y en la base territorial. Todo ello activa nuevos flujos migratorios que nutren de contingentes humanos las pequeñas ciudades gallegas en crecimiento (particularmente las del eje litoral) y de proletariado las fábricas de Bilbao y Barcelona y de los países europeos que aceleran en la postguerra su industrialización. Los que permanecen en el campo extreman sus capacidades para enfrentarse a la dominación exterior de su economía que se intensifica a partir de aquella década, aprovechando los recursos que el Estado (Instituto Nacional de Colonización primero y el IRYDA después) y las empresas para las que trabajan (v.gr, el sector lácteo) ponen a su disposición (Iturra, 1999:100-101). Además la disolución plena del campesinado parcelario y de los restos de 
su estratificación interna exigen del agricultor-empresario su complicidad con el sistema triunfante. El umbral que permitía la salida de la economía campesina fue cruzado de manera definitiva cuando pasamos a la década de 1990 y la racionalidad imperante en la esfera capitalista convierte en inservibles buena parte de los mecanismos extraeconómicos que perviven y son aprovechables en la coyuntura aldeana anterior a 1980. Cuando Iturra (1988:95-99) realiza su trabajo de campo entre 1975 y 1977 los comportamientos propios de la lógica campesina, como ciertos dispositivos y prestaciones basadas en la reciprocidad y tareas comunales aún vigentes para el aprovechamiento del monte, se interpolan con las estrategias optimizadoras del "productor/empresario agrícola". A su vuelta al mismo territorio veinte años después detectará Iturra las nuevas mudanzas y dirá expresivamente: "La tierra patriarcal pasa a ser título de los más jóvenes y aptos, para que puedan garantizar la continuidad de las inversiones, recuperados en producción lucrativa para el Estado Español y para las empresas que trabajan con estos nuevos campesinos, ahora empresarios aprendidos. En el conjunto de las aldeas que estudié, observé que sólo 2 de entre 400 casas tenían alternativas de futuro" (Iturra, 1999:101-102).

La situación actual de Galicia viene dada por el cambio radical de sus parámetros históricos donde la urbanización de su sociedad camina paralelamente a los procesos desagrarizadores, a pesar de las potencialidades que muchos relatores y protagonistas ven en varios de sus sectores productivos agropecuarios, comprendidos hoy como ámbitos significados de una agroindustria ligada a la ganadería, la producción vitivinícola y la producción forestal y silvícola. Pero es el desajuste demográfico lo que más preocupa, apareciendo la cuestión reflejada en los medios de comunicación con inusitada frecuencia. Los economistas marcan la ruta para aproximaciones actualizadas a la cuestión cultural y social desde las diversas disciplinas sociales, entre ellas la antropología que ha puesto su mirada también en el mar y en su vida litoral (Calo, 1984; 1996; 1998; 2014; García Allut, 1993), donde la Galicia marinera, correlato costero de la Galicia campesina en el imaginario cultural difundido por los etnógrafos, intelectuales y publicistas del pasado, pero viva todavía en las representaciones del presente, no ha desparecido completamente coexistiendo la pesca artesanal con una pesca industrial de altura muy desarrollada tecnológicamente y estrechamente ligada a otras actividades extractivas e industriales, en las que ocupa un papel y tiene una indiscutible imagen la industria conservera, asociada a la expansión urbana de Vigo y de otras ciudades y villas del litoral galaico.

Lo indicado encauza el itinerario de la Galicia presente, condicionado por un proceso de envejecimiento de su población inseparable de un descenso alarmante de sus efectivos, cuya relevancia no parece ser captada en toda su dimensión por los agentes políticos y por buena parte de la población: "El consenso gallego basado en el silencio, en la resignación y en la evasión sobre nuestro desastre natalicio, sin parangón en todos los países con 
identidad evidente, es el peor de los enemigos para revertir la situación [...] Galicia tampoco se caracterizó en las últimas décadas por demandarle al Estado una política integral en este aspecto [...] la patología de la infima fecundidad gallega no obedece a ninguna causa señaladamente preponderante, sino a un probable cúmulo de causas que actúa también de manera distinta sobre un conjunto de grupos sociales, que se retroalimentan y apuntalan entre sí." (Blanco, 2014:38-39).

Ante el panorama descrito, ¿reflejan los museos gallegos la trayectoria de su contemporaneidad y las incógnitas del presente; son espejos, particularmente los etnográficos, en los que se refleja la reconfiguración de imaginarios que los cambios intensos y acelerados ocurridos en Galicia en los últimos decenios provocan? Los dispositivos museográficos no pueden crear, ni es esa su función, expografías detalladas con relatos profusos y prolijos de la sociedad y la cultura de un territorio. Tampoco deben inhibirse del relato que enuncia, cuenta o sugiere lo vivido y experimentado recientemente. La situación sociodemográfica sintéticamente comentada, la coyuntura actual -superación del declive comenzado en la década de 1970 con la creación entre 1997-2008 de 400.000 empleos netos al margen del sector agropecuario- y un crecimiento del PIB inferior al de las CC.AA. más dinámicas del Estado español (Vence, 2011: 20-22), condicionaron un cuadro necesariamente nuevo en sus significados y en sus comportamientos socioculturales. La complejidad dialéctica entre lo local y lo global asoma en "un proceso de desagrarización intenso -y extremo- [combinado] con un importante proceso de terciarización ... que no alcanzaba los niveles de la economías europeas", porque el problema reside en la fragilidad del modelo de neoliberalismo periférico en el que se asentó este crecimiento, inviable para territorios alejados de los centros de decisión e ilustrativo del juego de asimetrías en el que operan las diversidades económicas, sociales y culturales. $\mathrm{Y}$ esto, con sus interpretaciones, testimonios y narrativas, sí es competencia de un museo de sociedad, concernido por el tratamiento etno-histórico de sus contenidos (Barroso y Vaillant, 1993) y que reclama para sí la tarea de ser un escaparate de los imaginarios que transitan por las mentes de muchos ciudadanos y vecinos y de dar voz, contextualizada con documentos, objetos e imágenes, a la realidad que asoma ante sus ojos y a los comentarios que llegan a sus oídos. A los suyos y a los nuestros.

\section{EVOLUCIÓN DEL MUSEO EN GALICIA. SUS PRECEDENTES Y SU DESARROLLO}

Antes de responder a los interrogantes anteriores debemos resumir la historia museal de Galicia, señalando los rasgos más significativos de aquel proceso. El museo como institución cultural inscrita en las prácticas y discursos centrados en el patrimonio cultural va tomando cuerpo en Galicia durante los años de la transición política, siendo 
muy escasas las entidades museísticas creadas antes de 1970. Hemos llamado la atención al respecto (Sierra, 1999: 304; 2003: 213-214) y apuntado que, comparado con otros territorios y estados, el museo era una realidad minoritaria, restringida a unos pocos y por la que la sociedad manifestaba escaso interés. Es sintomático que, en el momento en que se producía en Europa una turbulencia crítica (Clair, 1992; Varine, 1992) destinada a cuestionar y replantear el museo consolidado en la modernidad, esta institución era en Galicia un hecho menor, poco estimado y casi desconocido. Nos encontramos en la fase final del tardo-franquismo y en los albores de la transición política con 19 entidades museísticas, de las cuales 8 son anteriores a 1936, 5 aparecen en el primer período franquista y 6 después del Plan de Estabilización de 1959. Debemos recordar que a los 8 museos creados antes de 1936 hemos de añadir 3 más, el más antiguo, aparecido entre 1903-1904 (Pérez, Serrano y Vilar, 1997), posee el interés de ser el primer museo etnográfico de Galicia (Museo de Pías, Mondariz, Pontevedra) y los otros dos se crean entre la dictadura de Primo de Ribera y la República. Uno de ellos, el Museo Pedagógico Regional, no consolidó una exposición permanente y el otro, el Museo ArqueolóxicoEtnográfico de Galicia, creado por el Seminario de Estudos Galegos-SEG (Mato, 2001) en Compostela estaba prácticamente formado en 1930. Ninguno de los tres perduró después de 1936, disolviendo las autoridades franquistas el SEG e incautándose de sus fondos, biblioteca y fondo documental. Con ello desaparece del paisaje de Galicia hasta 1970 la imagen del museo etnográfico, con la excepción de las pequeñas secciones de etnografía existentes en los museos provinciales de Ourense (la más significativa), Pontevedra y Lugo. El Arqueolóxico de Ourense ${ }^{1}$, consecuencia de las acciones desamortizadoras y producto de la gestión de la Comisión Provincial de Monumentos, es el único museo centenario de Galicia y el único también existente en el país en el siglo XIX (Barriocanal y Fariña, 1989).

Al día de hoy, encontramos 84 entidades museísticas registradas en el Censo oficial de la Xunta de Galicia ${ }^{(22)}, 65$ de las cuales fueron creadas a la vuelta de 1970 y el mismo Censo contabilizaba 56 entidades en 1993 y 74 en 2003, lo que nos sugiere que los períodos más activos fueron los comprendidos entre 1970-1993 y 1993-2003, aunque tal estimación puede resultar engañosa, porque en el segundo de esos períodos y posteriormente a 2003 se crearon museos y colecciones visitables que no aparecen registrados todavía por la Administración con competencias en patrimonio cultural y museos, ya que sus promotores no han solicitado el pertinente reconocimiento en el Censo oficial. No es fácil calcular con precisión el número de entidades que se hallan al margen de la disciplina

1. Del que procede, como sección Etnográfica primero y como museo con entidad administrativa propia después (1993), el Museo Etnolóxico ubicado en Ribadavia-Ourense, materialización alternativa del museo propuesto anteriormente por Chamoso (1974).

2. http://museos.xunta.es/es/museos/lista/tsec.tid/asc [2014] 
administrativa, pero no iríamos descaminados si estimamos que podríamos sumar a los 84 reconocidos unas 35/40 entidades más, lo que significa que habría que incrementar el cómputo total en un 30/35\%. De hecho sólo en la provincia de Ourense, donde hemos realizado un examen más detallado, tenemos contabilizados 20 casos seguros de instalaciones museísticas o paramuseísticas, buena parte de ellas, curiosamente, dependientes de las Administraciones locales (por lo tanto iniciativas públicas) y cuya ejecución ha contado también con recursos públicos, en varios casos de la Administración autónoma responsable de llevar el Censo citado y de supervisar, conforme a la normativa legal de aplicación, si esos centros cumplen los requisitos técnicos exigidos.

No nos detendremos aquí en la descripción de la secuencia fundadora de museos en Galicia, cuestión tratada en otros trabajos (Sierra, 1999; 2000; 2003), aunque sí señalaremos que es a partir de 1990 cuando la iniciativa local y, dentro de ella, la municipal se suma a la creación compulsiva de pequeños museos en un marco de concurrencia de ayudas de la UE, canalizadas a través de las figuras de desarrollo local y comunitario y en el momento en el que el sector agrario y el mundo rural atraviesan por un reajuste intenso y, como hemos dicho, acelerado. La población ocupada agraria desciende entre 1985 y 1997 en un 60\%, aunque esta desagrarización (López Iglesias, 1997:220-222; 1998:13) no conlleva un abandono residencial del rural en la misma cuantía, lo que nos indica que en la aldea permanece un conjunto apreciable de actores económicamente pasivos, aunque activos en otros planos, pero no lo suficiente para encabezar iniciativas socioculturales. Los agentes políticos locales ocupan el vacío dejado por los actores sociales más jóvenes, ausentes, y tienen ante sí el desafío de gestionar acciones alternativas que compensen los desequilibrios económicos, sociales y demográficos ocasionados por el proceso desagrarizador. En un momento en el que los mercados supralocales difunden la alternativa turística (Santana y Estévez, 1996: Santana, 1999) como panacea para áreas deprimidas, alcaldes y gestores locales importan la noción de patrimonio cultural debidamente segmentada por los discursos académicos y jurídicos, por las administraciones mayores y por los medios de comunicación. Hay que explorar el territorio e identificar todo aquello que pueda ser traducido en términos culturales para recibir el estatuto de patrimonio cultural. Los espacios del trabajo, recuerdo reciente de la cultura campesina, abandonados en muchas casos, despiertan un interés inusitado gozando de un tratamiento inédito. Para que funcionen como monumentos (Sierra, 2000:452) -pues no se concibe de otra manera el patrimonio cultural- conviene someterlos a intervenciones donde la pulcritud restauradora fagocite el repertorio de memorias convenientemente olvidadas, para enaltecer el bien cultural neófito y convertirlo en testimonio de las arcadias que convivían en armonía con la naturaleza. El museo que se crea en este proceso contiene pocos relatos, ya que si los objetos expuestos 
en ellos hablaran, disolverían el ambiente bucólico sobre el que se reinventa una tradición ajena a las contradicciones y a las coyunturas bien recientes, responsables del desajuste desagrarizador y del abandono de construcciones, lugares y herramientas, así como de la marcha de su gente hacia horizontes más esperanzadores. Muchos de estos museos promovidos a lo largo de los años noventa del pasado siglo y en la primera década del presente se constituyen al abrigo de estos parámetros. Un porcentaje significativo gozó de las ayudas concedidas por las administraciones intermedias (Diputaciones) y mayores (Xunta, Estado y programas Leader, Proder, etc.) y en los últimos años, acentuado por los recortes presupuestarios, se encuentran en una situación de inacción, parálisis o cierre. Su actividad documental, conservadora o divulgadora es escasa o nula y su dependencia económica de las administraciones que coadyuvaron a su creación y apertura, los aboca actualmente a la situación apuntada. Las posibilidades de extinción o amortización de estas musealizaciones rurales se intensifica con la limitación de aportaciones de sus gestores y con la supresión de subvenciones y ayudas de las administraciones subvencionadoras mayores, lo que las mantiene aisladas en contextos sociales carentes de actividad cultural asociativa (Mairesse, 2012:61). El desajuste demográfico condiciona negativamente el surgimiento de actores sociales en la base de la comunidad y, por lo tanto, de juventud emprendedora que promueva iniciativas al margen de la intermediación y tutela político-institucional. Este vacío es ocupado, como indicamos, por los agentes políticos de la comunidad local que mediatizan el vínculo entre vecinos y representantes de las administraciones mayores, las dotadas de potencialidad para aportar, intermediar o captar los recursos financieros y los apoyos técnicos que estas patrimonializaciones y musealizaciones precisan (Sierra, 2003:230-31).

Este cuadro general, que cobra mayor relieve en los territorios de la Galicia interior y está menos acentuado en los de la franja litoral, muestra la opción fallida de la patrimonialización cultural en Galicia y el desencanto ante los escasos réditos obtenidos frente a la esperanza depositada en el aprovechamiento turístico de los pequeños patrimonios locales, desvestidos de unas grandezas inexistentes y de las subordinaciones y miserias sobre las que se habría construido la verdadera identidad basada en el trabajo, en sus matrices identitarias y en las representaciones simbólicas hurtadas en estas musealizaciones al discurso nativo (hipostasiado y/o ausente). La ocultación del discurso nativo se refleja en el silencio de los objetos musealizados, en su fosilización como muestras de un pasado intemporal, sin cambios ni permanencias explicadas y ayuno de presente, que convierte su museografía etnográfica en fotocopia reiterada de sí misma. Un pasado mutilado y un presente huido no pueden ofrecer significados al visitante ni construir relaciones de sentido para los allegados a la comunidad de la que es oriundo este patrimonio. 


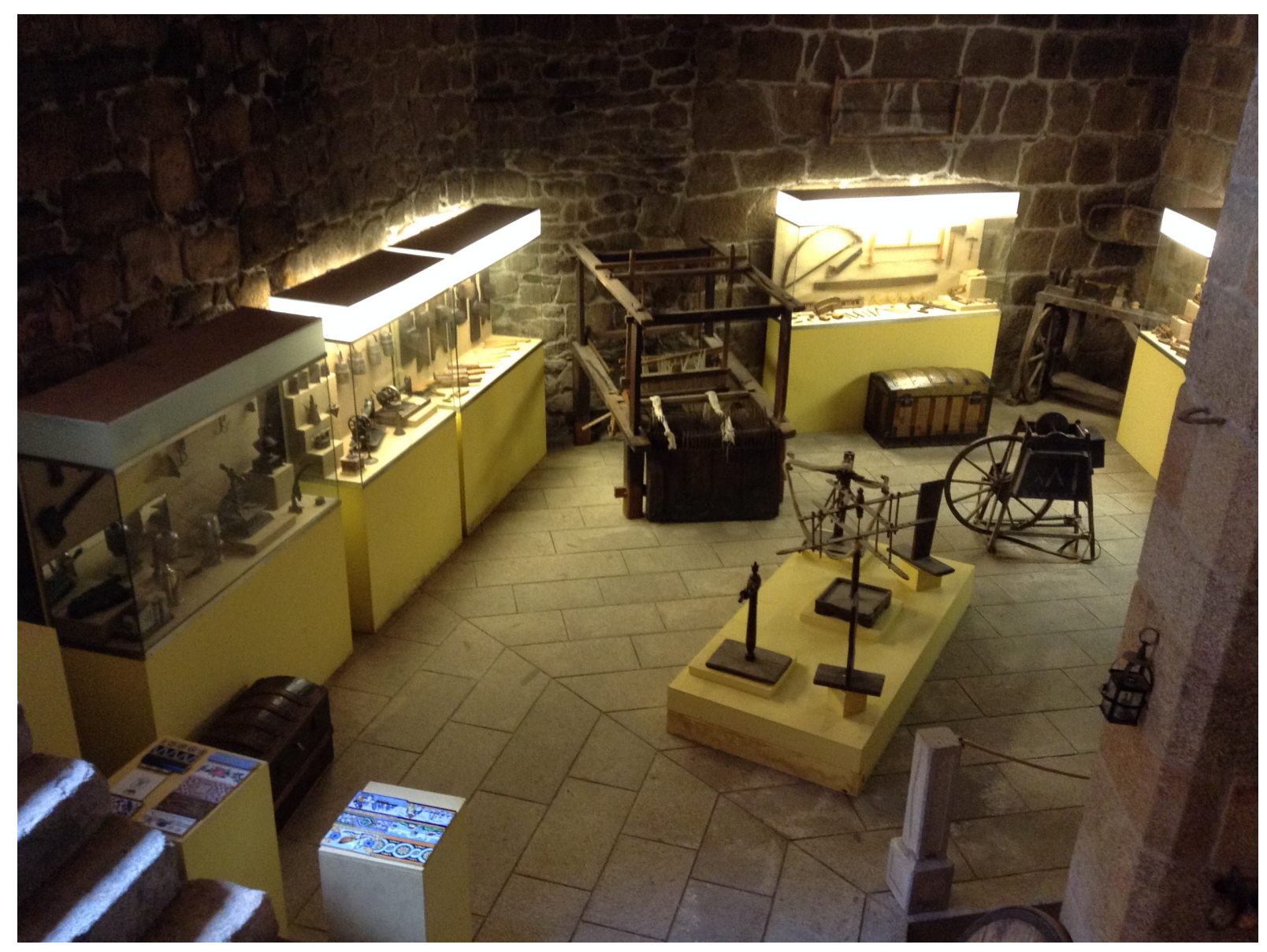

Foto 1: Museo Etnográfico de Castro Caldelas

Aunque igualmente enrocadas en la concepción pasadista y ruralista de lo etnográfico, encontramos en Galicia otros ensayos de musealización etnográfica con propuestas más coherentes y con prácticas socioculturales activas y conectadas con su entorno. No nos parece casual que buena parte de los casos, cuyas representaciones museográficas comentaremos en el siguiente apartado, hayan sido promovidas y creadas en los tiempos de la transición o al comienzo de los años ochenta del siglo pasado, sin duda con anterioridad a la difusión del espejismo reduccionista del turismo y a la convicción fatalista de que los procesos socioeconómicos del agro, con su descampesinización plena y su gradual desagrarización, eran irreversibles. Surgen estos casos paralelamente a la aparición del Museo do Pobo Galego (MPG), fuente de inspiración y de mímesis, muchas veces desafortunada para la museografía etnográfica de Galicia posterior a 1985/1990.

Difícilmente podemos desfetichizar la museística etnográfica en Galicia si nos encontramos con la barrera de que sus textos legales (Pereiro, 2009; Sierra, 2000) asumen una definición que choca frontalmente con el análisis desarrollado por la disciplina que 
debiera inspirar sus musealizaciones. Esta concepción ha fosilizado la idea de etnografía y lo etnográfico reduciéndola a un espacio territorial y a un ámbito sociocultural prefijado que, al haber mudado de piel y de camisa, han convertido la mayoría de los museos etnográficos gallegos en lugares arqueológicos reificados en sus limitaciones y contradicciones.

Consecuentemente y respetando la denominación como museos etnográficos de quienes el Censo oficial de La Xunta así clasifica, deberíamos abrir un debate para aplicar nuevas lecturas a muchos museos no catalogados como etnográficos; museos susceptibles de ser observados con mirada etnográfica, por cuanto sus colecciones y, especialmente, su perfil museológico posibilitan un nuevo enfoque en el que cabe un diálogo sobre la bipolaridad identitaria que, entre visillos, asoma en esos museos posibilitando la circulación del yo y del otro. Creemos que este ejercicio de revisión de las clasificaciones formales y oficiales de los museos posibilitará un encuentro entre las ciencias sociales y el museo y, particularmente, entre el museo y la rica y variada tradición científica antropológica. El mapa museal de Galicia se encuentra en dique seco, ya que administraciones en general, mundo académico y sociedad civil adoptan actitudes pasivas, cuando no inertes, frente a la patrimonialización cultural y a la museología como campo de conocimiento aplicado e implicado. El papel de la Administración competente en estas materias, con sus conexiones e implicaciones sociopolíticas y culturales, ha sido tratado y analizado por Xerardo Pereiro con singular acierto (2006; 2008; 2009; 2012). Ahora corresponde profundizar en las hipótesis y en los planteamientos que nos ayuden a comprender el conjunto de variables y de comportamientos que los distintos agentes sociales e institucionales adoptan y han adoptado, para comprender en su complejidad las prácticas desarrolladas y las nuevas miradas que el museo recibe desde otras instancias como el sistema arte-cultura y desde los marcos de convivencia cultural que la ciudad y la villa y también los espacios periurbanos y rururbanos respiran. La antropología, carente de visibilidad social en Galicia (Pereiro, 2001) y minorizada en sus tres universidades, y la etnomuseología tienen mucho que explorar, observar, debatir y decir. No constituye un aspecto menor la debilidad académica de la disciplina a la hora de entender el hecho de que la visión del museo etnográfico en Galicia y de lo etnográfico, como calificación, apenas hayan cambiado en los últimos años, pues esa invisibilidad permite que el discurso etnográfico y las patrimonializaciones y museos resultantes sea hegemonizada por quienes no promueven un enfoque interdisciplinar y por los que reducen lo etnográfico a los parámetros de la arqueología, la arquitectura y la historia del arte (Pereiro, 2012:32). Demasiados tabiques metodológicos para el diseño de un loft epistemológico.

El distanciamiento entre antropología y museo no es privativo de Galicia ni del conjunto del Estado español. Ha sido planteado en la museología europea (Desvallées, 1994:52- 
53; Jamin, 1998:66; Korff, 1996:121-122) y tuvo su debate precoz en España a raíz de la celebración de los Congresos de Artes y Costumbres/Tradiciones Populares (Esteva, 1968; Limón, 1983; Romero de Tejada, 1985) y de las Reuniones de Antropólogos Españoles de 1973-1974 (Fernández de Paz, 1996). El puente entre Galicia y estos debates, tamizado por la interpretación político-institucional de aquellos años, lo establece Manuel Chamoso Lamas quien defiende que se proceda "hacia una diligente y harto urgente y necesaria tarea de conservación" y "se recoja cuantas manifestaciones de la vida, usos y costumbres, se hallen prendidos en el entresijo de lo tradicional y que la vida y la técnica modernas ha desplazado" (Chamoso, 1974: 33 y 40). Podemos conectar esta preocupación con las intervenciones y sus consecuencias que la tecnocracia franquista desarrolla en el agro, de la mano del Instituto Nacional de Colonización (INC) y del Servicio de Extensión Agraria (creado en 1955), que introducen innovaciones técnicas -visibles aún hoy en el campo gallego- y nuevos modelos residenciales (los poblados de Colonización), que en Galicia tuvieron menor incidencia. En 1973 se funde el INC con el organismo de Concentración Parcelaria, dando lugar al IRYDA (Instituto de Reforma y Desarrollo Agrario), cuya significación e incidencia en Galicia fue apreciable. Estos cambios espolean la inquietud de las autoridades de Bellas Artes del momento por la salvaguardia y la conservación de un mundo en desaparición y, aunque exista una correspondencia cronológica evidente y un cruce entre las iniciativas musealizadoras de la Administración y los debates y documentos académicos citados, la influencia mutua fue relativa.

\section{EL MUSEO COMO ESPEJO Y REPRESENTACIÓN DE LAS IMÁGENES CULTURALES DE GALICIA}

El museo en su construcción histórica se ha ido configurando como un campo de la reflexividad de los individuos y de su cultura. Todos ellos, sean de historia o arqueología, de historia del arte o de las artes plásticas contemporáneas, de las ciencias y las técnicas, de sociedad, etnología o de las distintas variantes y secuencias de las no tan nuevas museologías (Iniesta, 1994:62ss) activan dispositivos identitarios. Unos colectivizando el repertorio patrimonial de grupos y comunidades locales, otros atribuyendo ciertos bienes culturales a la singularidad de un estado o nación, otros muchos enunciando postulados cosmopolitas que trascienden fronteras, pero siempre aplicando la lógica del límite en cuanto incluyen y excluyen hechos, signos o valores, y el resto significando y enalteciendo las individualidades en la creación artístico-musical, en el deporte o en la ciencia. Unos movilizarán elencos emocionales de comunidades étnicas que se imaginan como comunidades políticas. Otros, bajo pretendidas racionalizaciones de la lógica globalizadora, disolverán imaginarios identitarios parciales o menores sublimando la unidad de un mundo sin fronteras. Pero aun en este caso, como varios autores sugieren, 
las condiciones de globalización son, teórica y empíricamente, inseparables de las de desglobalización. Recientemente García Canclini (2003) postulaba la oportunidad de un museo de la globalización ante las contradicciones que los procesos trasnacionales sufrían, originando dinámicas centrífugas que alertan, cuestionan o combaten los itinerarios asimétricos de la globalización. En el museo de García Canclini habríamos de examinar y mostrar cómo y quiénes ponen en circulación en el ámbito local los significados y las representaciones adquiridas y asumidas en lugares distantes (Hannerz,1998:53), planteamiento que ayudaría a comprender los comportamientos y prácticas culturales de los emigrantes gallegos (Núñez Seixas, 1998:307ss; González Reboredo, 1999) en los puntos de destino y en la tierra de origen después del retorno, y permitiría analizar los discursos y posicionamientos adoptados ante la patrimonialización cultural y sus musealizaciones acometidas en el medio rural y, también, en las villas y ciudades.

Aplicando este enfoque, quien quisiera ver, en su diversidad interna, los elementos diferenciadores de la cultura gallega a través de sus museos no podría limitarse a la visita al Museo do Pobo Galego, por más que esta sea necesaria. Dado que las identidades culturales se producen, reproducen y transforman en la historia, si el MPG nos muestra las dimensiones más expresivas de la cultura popular anterior a los grandes cambios que la sociedad gallega experimentó en los últimos años, el Museo de Pontevedra, el MUBAC de A Coruña, el Museo Pazo Quiñones de León y el Museo Laxeiro de Vigo o el Museo Manuel Torres de Marín esconden otras identidades, las elaboradas por los artistas plásticos de finales del siglo XIX y de los primeros decenios del XX que, al observar los espacios y las gentes de su entorno, han idealizado tipos y figuras o transformado en ensoñaciones los paisajes, dándole una réplica estética a los testimonios del folklore y al relato etnográfico de los autores anteriores a 1930. En varios de estos museos estas obras conviven con otras alineadas en las tendencias vanguardistas que emergen entre $1925 \mathrm{y}$ 1936 y que asumen postulados estéticos renovadores que sustituyen la estampa folklórica por una iconografía estética que encaja en la búsqueda de una identidad nacional, donde el arte contribuye a la expresión visual de la comunidad política imaginada (Castro, 1992). Si damos un salto en el tiempo y, sin dejar totalmente los museos citados, nos acercamos al Centro Galego de Arte Contemporáneo (CEGAC) en Santiago, al Museo de Arte Contemporáneo de Unión Fenosa (MACUF) en A Coruña, o al Museo de Arte Contemporánea (MARCO) en Vigo, veremos cómo alternan, conviven y se enfrentan obras internacionales de las distintas artes plásticas con la creación gallega posterior al grupo Atlántica (1985), definido por sus críticos y asumido por sus protagonistas como "el vínculo de la creatividad artística a un territorio antropológico", limitado por su posición "atlántica" (Castro Borrego, 1992:326-327). La representación de la artes plásticas gallegas globalizadas, con cultivadores y militantes del surrealismo, como 
Eugenio Granell, o intérpretes a su manera del cubismo como Luis Seoane, verdaderos ejecutores de una manifestación glocal de la identidad gallega repensada y distanciada en el tiempo y el espacio, puede verse en los museos de sus fundaciones respectivas en Santiago (Fundación Granell) y A Coruña (Fundación Luis Seoane) y también, con relación a la obra de Seoane, en el Museo Carlos Maside de Sada (A Coruña) ligado a las porcelanas de O Castro y a la figura del artista, polígrafo y editor gallego Isaac Díaz Pardo, recuperador en sus fábricas y en el museo homónimo de las lozas y porcelanas de Sargadelos, icono identitario, sabiamente mercantilizado, de la Galicia contemporánea. Si estos museos nos muestran la identidad creada por las artes, en ellos nos familiarizamos con la identidad individual del artista, aquel que, como Castelao (Museo de Pontevedra y Museo Carlos Maside), utilizó el dibujo para reflejar una identidad (López Vázquez, 2000), al tiempo étnica y social, trazada a través de pinturas, dibujos y caricaturas tamizadas por la clase y el género. Muchas veces, la individualidad del artista y su proyección exterior le confieren atributos identitarios compartidos por sus comunidades de origen, que les reconocen un perfil canónico y con cuyos rasgos y significados se sienten identificadas.

Formulado veinte años atrás, el sistema arte-cultura no ha gozado de gran predicamento en los ámbitos museológicos hispánicos, donde si alguna oposición era evidente era la que se percibía entre el museo etnográfico y el de arte o bellas artes. La dificultad para formular desde una perspectiva holística la noción de cultura y, con ello, la integración de las manifestaciones artísticas (sensu lato) en los museos etnológicos ha alejado el arte de la mirada etnomuseológica, produciendo un hueco significativo en los debates y en los planteamientos de la museología etnográfica. Cierto es que este alejamiento se percibía en ambos lados, pues no era habitual en los museos de arte producir relatos sobre la identidad o comprender el arte como parte del sistema cultural total y como marco de sus perfiles simbólico-morales. Los museos gallegos que acabamos de citar no han entrado tampoco en este debate, aunque, independientemente de que lo planteen o lo asuman, no pueden evitar ser objeto de una mirada global y de que lo que muestran nos acerque al fenómeno de la identidad y posibilite su interpretación cultural. Debemos recordar que hace poco tiempo los museos etnográficos eran denominados, por influencia francesa, "museos de artes y costumbres/tradiciones populares", debido a que la incorporación a sus musealizaciones de fondos producidos por los practicantes de oficios artesanales, también llamados artes menores, justificaba semejante denominación. El sistema arte-cultura, que Clifford (1995:257ss) examina críticamente al pasar revista a los bienes culturales de los pueblos colonizados por Occidente y que motivaron la creación en su día de los museos de la Völkerkunde, podríamos extrapolarlo a nuestras diversidades internas donde los museos etnográficos (de artes y tradiciones populares o de la Volkskunde) han ido por caminos divergentes a los museos de bellas artes y a los 
de plástica contemporánea. La búsqueda de convergencia entre estas diferentes fórmulas museológicas explica la reconversión o replanteamiento de grandes museos etnográficos de Europa -varios de ellos pertenecientes al RIME (Réseau International de Musées d'Ethnographie)- que han modificado sus postulados y museografías (Sierra, 2013:117).

Lo que hemos planteado al hacer este brevísimo recorrido por los museos con colecciones de plástica gallega de finales del siglo XIX y de etapas sucesivas del siglo XX es mostrar cómo la divergencia puede convertirse en convergencia, una vez analizadas las contradicciones museológicas y el papel del artista plástico como observador de otros próximos. Cada creador encaja en un escenario de relaciones complejas donde él, la sociedad en la que se inspira, las imágenes que trasmite, los valores que los observadores y consumidores de su arte comparten y el denso andamiaje económico y simbólico en el que su producción se inserta, se encuentran y se cruzan. Y en este marco emerge la identidad como habitus o juego de disposiciones (Bourdieu, 1997:16) y también como proceso. Por ello y aunque el peregrinaje de las artes (mayores y menores) hacia la esfera antropológica de la cultura sea lento y el viaje del museo etnográfico hacia aquellas se haya demorado, no cabe duda que operamos con observatorios panorámicos del binomio sociedad-cultura. Se trata, de hecho y parafraseando a Clifford (1995: 153-154), de localizar nuevas conexiones entre la mirada antropológica y la perspectiva literaria y artística, capaces de proporcionar significados alternativos de lo propio y de lo ajeno.

Hemos de decir que esta visita a los museos de artes plásticas y bellas artes constituye una escapada heterodoxa para quienes sitúen en otro ámbito al museo etnográfico. En Galicia, aunque no sólo allí, el museo etnográfico es todavía hoy para la mayoría de los agentes sociales otra cosa. Pasados varios años desde que museólogos y etnólogos gallegos hicimos nuestras primeras catas sobre esta cuestión, los cambios de enfoque han sido mínimos. La incorporación de las Administraciones gallegas al mundo del museo, promoviendo su extensión en el territorio, no ha supuesto una modificación de planteamientos y, consecuentemente con ello, tampoco una modificación de su concepción de las tipologías museísticas sancionadas en los manuales al uso. Aunque la sociedad gallega, su territorio, sus estructuras económicas, sociales y políticas hayan cambiado profundamente, las categorías que delimitan cada variedad museológica permanecen prácticamente inalteradas. El viejo complejo agrario desaparece aceleradamente, aunque conserve sus islas de historia y sus lógicas campesinas persistan en los habitus y disposiciones culturales de gentes desenraizadas físicamente del rural (Lois y Piñeira, 1998: 207-208) y en un número significativo de personas de edad que permanecen en sus aldeas manteniendo activas, para su autoconsumo, y con prácticas análogas a las del antiguo campesinado parcelario, huertos y pequeños cultivos. En los 
territorios vitícolas perduran manifestaciones de trabajo informal o ATP, protagonizadas por los pensionistas que residen en la aldea o por sus hijos que conjugan sus actividades laborales en la ciudad con escapadas de fin de semana y en las vacaciones para mantener el viñedo en un territorio de herencia igualitaria y al que se sienten muy ligados. Un pequeño capital material es reproducido en términos de trabajo ocasional-informal (Lomnitz, 2003, 147-140) y traducido como capital simbólico, que robustece el sentido de adscripción y pertenencia de estas personas a su aldea y a las casas de sus maiores.

Las ciudades y villas más activas, con efectivos poblacionales más numerosos y dinámicos (desde la lógica positiva del progreso), absorben los excedentes y plusvalías de identidad que proyectan una imagen alternativa (y mayoritaria) de la sociedad gallega: una identidad urbana cuyas referencias al mundo rural son distantes o indirectas. A pesar de convivir en una sociedad con sectores industriales significativos -muchos de ellos, con una historia que no es reciente (conservera, pesquera, naval, automovilística, textil...) y que ha sufrido, en ciertos subsectores, desajustes y reconversiones brutales (Cardesín, 1999a)-, de haber desarrollado sectores especializados en el ámbito agro-industrial (leche, carne, vino y forestal) y de surgir en los medios urbanos un sector terciario relevante y, en su seno, un desarrollo universitario muy significativo, con tres universidades y siete campus, lo etnográfico, como señala Pereiro (2012:27-29), sigue siendo para la mayoría (instituciones y medios de comunicación incluidos) el mundo rural preindustrial carente de las narrativas que testimonian los avances y los desequilibrios asociados al cambio, entre ellos la mecanización del agro o las prácticas residenciales en la ciudad desarrolladas por las emigrantes retornadas (Ruiz, 1999) o por intervenciones drásticas sobre el territorio y sus formas residenciales, caso de embalses y explotaciones mineras (Herrero, 1999).

No vemos en ningún museo gallego reflejada la mudanza acontecida y tampoco sus resultados, y no vemos asumida como realidad descrita por el método etnográfico las experiencias, los sucesos, los testimonios, los objetos y las imágenes de este relato. El patrimonio industrial se somete a la mirada arqueológica, arquitectónica e ingenieril careciéndose en Galicia de una visión museológica multidisciplinar de su tradición industrial y de un reconocimiento de la fecundidad etnográfica de sus diversas manifestaciones. Algunos ejemplos del relicario industrial son objeto de reivindicación reciente por colectivos ciudadanos y de tensiones con la administración municipal, como ocurre con la Panificadora de Vigo ${ }^{3}$ y con La Molinera de Ourense (Cátedra, 1998).

\footnotetext{
3. La Panificadora de Vigo era una instalación industrial creada por cuatro panaderos locales que viajaron a varios países europeos en 1924 para importar conocimientos tecnológicos punteros en aquellos años y montar una planta capaz de abastecer a una población de 150.000 habitantes. La Molinera de Ourense era una planta industrial para la molienda de harinas, que motivó el interés de un colectivo vecinal perteneciente al barrio en el que se encuentra el edificio, que reivindicó su conservación, parcialmente lograda.
} 


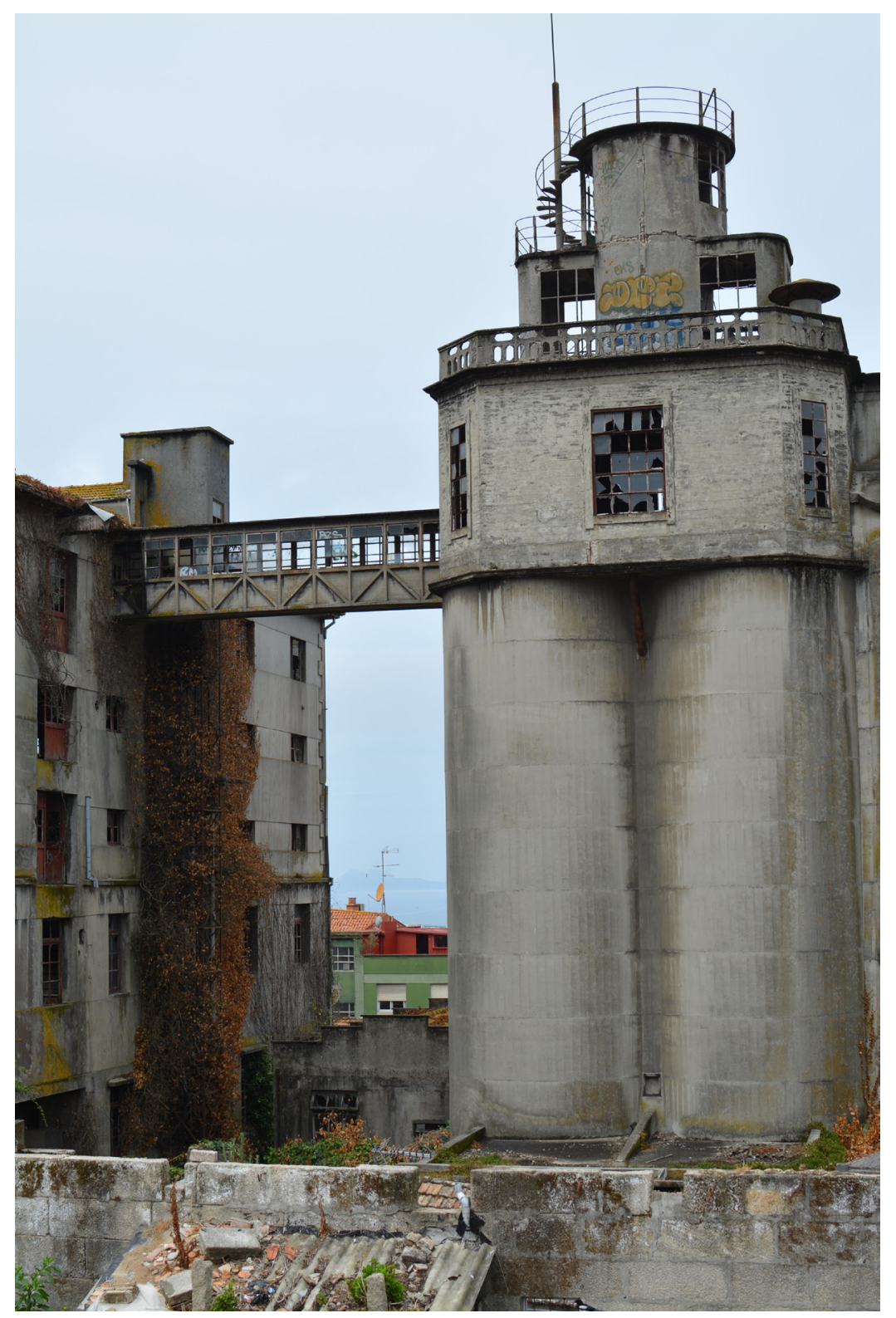

Foto 2. La Panificadora de Vigo. Reivindicación de la identidad industrial de una ciudad.

La estrecha correlación entre patrimonialización cultural y el sentimiento de nostalgia o de pérdida (Guillaume, 1980; Duclós, 1997) se manifiesta cuando colectivos vecinales, asociaciones cívicas y culturales muestran su sensibilidad hacia estos espacios, cuya conservación reclaman de las autoridades, que se inhiben en unos casos o reaccionan favorablemente en otros, según la coyuntura, el interés político y los intereses urbanísticos o la perspectiva de transformarlos en un recurso de explotación económica. Estas reacciones ante el abandono o destrucción de elementos de la actividad industrial del pasado se expresan a través de relatos historicistas o arqueologizantes, raramente 
mediante discursos polifónicos enriquecidos con la tesitura melódica de la antropología, lo que nos muestra una vez más la invisibilidad social de esta disciplina en Galicia.

Independientemente del enfoque disciplinar, el hecho verificable es el escaso interés o la reducida preocupación, culturalmente expresados, que la sociedad y las instituciones públicas muestran en Galicia por su tradición industrial. No existe ningún museo que se acerque a este fenómeno de forma multidisciplinar y el Censo de Museos de Galicia sólo incluye un museo privado de la industria conservera en Vigo (Museo ANFACO) que, por la naturaleza de sus promotores y titulares, y también por el contenido de sus fondos, tiende a relativizar la cuestión social y la tramoya simbólica de este fenómeno, central en la historia industrial del país. Posee este museo un interesante fondo fotográfico que, debidamente catalogado, ofrece muchas posibilidades para ampliar las cuestiones que contempla, básicamente centradas en la historia empresarial del sector y en lo relativo a la dimensión técnica de la producción industrial. Fuera de este caso, sólo el Museo del Mar de Vigo da cuenta de aspectos y dimensiones del mundo industrial cuyas prioridades, como sucede con muchos museos de la ciencia y de la técnica, optan por la difusión de relatos tecnológicos y no por el encaje de sus objetos y máquinas en el binomio sistema técnico-sistema social (Lemmonier, 2010; Sigaut, 2010).

Pero nada de lo indicado florece en la museística galaica, que ha optado hasta hoy por el olvido o la marginación de una tradición industrial muy relevante sin la cual sería inexplicable la historia contemporánea y la actualidad de las ciudades de A Coruña, Ferrol o Vigo y de sus entornos respectivos, poseedores de muestras tangibles y memorias presentes de las industrias del mar o para el mar: astilleros, conserveras, instalaciones pesqueras, tráfico marítimo, etc., cuyas huellas y actividad aún vigente nos llevan a otras ciudades costeras como Marín, Bueu o Cangas en las Rías Baixas o a los puertos pesqueros de las Rías Altas y de la Mariña luguesa donde encontramos el puerto de Burela, especializado en la captura del bonito del Cantábrico, y donde ha sido musealizada una embarcación para la pesca de este túnido, que mantiene operativos el conjunto de elementos que lo integran, lo que le ha valido un reconocimiento de la UE por la defensa de los recursos naturales y medioambientales. También en el Cantábrico lucense fue creado el denominado Museo Provincia do Mar (San Ciprián-Cervo), con fondos de una colección particular de historia natural y útiles de pesca y navegación, integrado actualmente en la red de museos de la Diputación de Lugo (Braña, 1997).

$\mathrm{Y}$ al hablar de patrimonio industrial no podemos olvidar que las innovaciones técnicas de maquinaria agrícola, insumos y fitosanitarios de fabricación industrial, llegadas a las explotaciones del "productor/empresario agrícola", son de importación, algunas, y de fabricación gallega otras, señaladamente Zeltia Agraria de O Porriño (Pontevedra), hoy 
adquirida por firmas multinacionales a la familia propietaria, fundadora también de la industria pesquera Pescanova, con base en el puerto de Vigo. Estos ejemplos y muchos más muestran los ámbitos excluidos de la patrimonialización cultural -arrinconados en el "trastero de la memoria" (Sierra, 2000)- en un país cuyo entramado industrial y agroindustrial y sus testimonios conforman el escenario donde se muestra la integración de este territorio en los circuitos transnacionales del capitalismo global. El reducido conocimiento y aplicación en Galicia de documentos como la Carta de Nizhny Tagil, promulgada en 2003 por el TICCIH (Comité Internacional para la Conservación del Patrimonio Industrial) reflejan tal exclusión. Algunas organizaciones como Buxa (Asociación Galega do Patrimonio Industrial) han trabajado con eficacia desigual para el reconocimiento y activación patrimonial de los espacios, que gozan, por otro lado, de una historiografía relevante (Carmona, 1990; 2005), aunque no de un enfoque antropológico como el postulado por diversos autores europeos (Morel y Vallerant, 1994).

Otras experiencias se han producido y otros itinerarios se han recorrido para manejar el museo en el escenario del reparto de patrimonios. En Galicia, y en muchas otras partes del Estado español, donde la mirada hacia el otro distante sólo ha existido de forma episódica, y generalmente asociada a prácticas misionales (Vázquez Varela, 2001), el museo etnográfico resulta de otro reparto o, más bien, de una disociación de patrimonios entre los florones de la alta cultura (Sierra, 2000) y los testimonios patrimonializados de los grupos, sectores y territorios subalternos. El peso de su sociedad agraria hasta tiempos recientes, reiteradamente señalado, motivó que para los intelectuales, historiadores, folkloristas y etnógrafos del Rexurdimento (s. XIX) y de las corrientes sucesivas de la generación Nós y del Seminario de Estudos Galegos (SEG), el agro y sus comunidades campesinas representasen el núcleo básico de la sociedad gallega. Sus condicionamientos teóricos les llevaron a entender que el campesinado era el sujeto histórico sobre el que reposaban los atributos más significativos de una historia larga que hundía sus raíces en la protohistoria y que, tras la romanización y el reinado suevo, había conformado un tipo de sociedad gestado en el medievo y en el antiguo régimen. El campesinado mantenía el idioma, había sido un agente decisivo en la ordenación del territorio (Bouhier, 1979) y seguía siendo un actor clave en la contemporaneidad de las actividades económicas, de los comportamientos sociales, de las celebraciones festivas y de las creencias religiosas. La tardía modificación de este escenario y la fijación intelectual y moral de estos marcadores explican, en parte, la concepción de la etnografía, de lo etnográfico y de la cultura que refleja la museografía etnográfica en Galicia. La ciudad representaba otra realidad, la del comercio y la industria, y su peso demográfico relativo en la sociedad hasta avanzado el siglo XX justifican su alejamiento de las miradas etnográficas, ya que 
la ciudad y sus ingenios rompen con la imagen de lo que hasta 1950 se había visto e interpretado como genuinamente gallego. La auctoritas de los intelectuales salidos de Nós y del SEG, que desaparecieron físicamente, la mayoría, entre 1950 y 1980, proyectó su relato y sus concepciones sobre las generaciones activas después de 1980, tanto entre los intelectuales (que reivindicaron unas figuras maltratadas o represaliadas por el régimen de Franco) como entre los gestores públicos de la democracia necesitados de amparo cultural y de discursos explicativos y legitimadores de su acción. Los grupos políticos progresistas y nacionalistas y el asociacionismo cultural asumieron también como herencia propia el legado de aquellos autores, aunque gradualmente fueran puliendo muchos de sus planteamientos, luego de recibir nuevos enfoques teóricos y metodológicos de la universidad de Compostela, heredera también, en cierta forma, de un legado vinculado entre 1923 y 1936 a sus aulas, ya que el SEG lo habían promovido estudiantes de la Universidad de Santiago y constituido y desarrollado conjuntamente varios de sus alumnos y profesores.

El período autárquico de postguerra, al suponer una vuelta atrás respecto de muchas innovaciones técnicas recibidas por el agro en el primer tercio del siglo XX, robusteció la imagen de un agro preindustrial y de un campesinado poco evolucionado y acantonado en sus costumbres "ancestrales". El cierre de fronteras a la emigración durante esa primera década de la postguerra incrementó la presión demográfica sobre la tierra, reafirmando la imagen de una sociedad mayoritariamente campesina y escasamente desarrollada.

Significativamente, la modulación yel cambio de este discurso intelectualmente dominante se produjo en los estudios históricos y arqueológicos y, según parcelas y períodos, en los de historia del arte. No así en la etnografía, carente hasta muy recientemente de estudios reglados universitarios que diesen la réplica a una concepción superada en muchos territorios de Portugal y España. Cuando la antropología llega a la Universidad (Fernández de Rota, 1992; Pereiro, 2001) se instala como área de conocimiento con débil implantación. El peso de un legado intelectual fuertemente difundido, la asunción simplificada en el ámbito político-institucional de lo más elemental de su discurso, la debilidad académica de la antropología, el desconocimiento social y mediático del vínculo epistemológico antropología-etnografía y la incorporación y normalización en la prensa, radio y TV del relato etnográfico prefijado explican de manera conjugada la visión de lo etnográfico en Galicia. Que los colectivos culturales y vecinales hayan igualmente interiorizado esa visión conduce al ensimismamiento y la mimetización de este fenómeno (Pereiro y Vilar, 2002:12). Hemos de precisar que, aunque este aspecto tuvo una divulgación limitada, los clásicos de la etnografía gallega, en sus trabajos de campo y en las publicaciones colectivas y multidisciplinares de preguerra, esbozaron 
interesantes planteamientos antropológicos, visibles en las monografías Terra de Melide (1933) y Parroquia de Velle (1936), que no excluyen la dimensión social, el género y la relación campo-ciudad.

Nos encontramos por ello un amplio y extendido repertorio de museos etnográficos en los que prima la ruralidad estancada y sin una narración, textual o visual, de los cambios, con panoplias de objetos silentes, que por su antigüedad crean una atmósfera arqueológica en la que el peso de sus museografías recae en los objetos y no en una combinación articulada de objetos, imágenes y palabras. El relato visual -fotografías o filmaciones adecuadamente seleccionadas- está ausente y la fuente oral, clave para reconstruir el discurso nativo y aportar legitimidad al montaje museográfico, no aflora. Con ello las exposiciones no emiten señales dinámicas y contextualizadas y alejan a la comunidad del museo. El manejo de estos elementos y, especialmente, su conjugación no sólo proporcionaría imágenes del cambio y de las memorias de las mudanzas, sino que proporcionaría reflexividad, en su dimensión teórica y práctica, a las acciones musealizadoras (Padiglione, 1999: 218-221). Aun así para la compresión de la ruralidad representada es preciso que los objetos se desprendan del halo de intemporalidad que prima en la mayoría de los museos etnográficos gallegos, llenos de objetos sin fecha, incapaces por ello de establecer un enlace con otros objetos y de relacionar la innovación agro-industrial con los contextos en los que se manifiestan los procesos de modernización.

Frente a un conjunto numeroso de museos que repiten miméticamente las museografías descritas, vemos que son los centros creados antes de 1990 -con la excepción del Parque Etnográfico del Río Arnoia (Allariz) y del Museo de A Limia (Vilar de Santos)- los que han desarrollado una tarea más estable y acorde con los planteamientos museológicos. El Museo do Pobo Galego, aceptado por todos como el referente de la museología galaica y el buque insignia de su museografía etnográfica, comenzó su andadura asumiendo como propia la visión cultural de los etnógrafos del SEG (Braña, 2008:38ss) y organizando sus primeras salas según el guión de la obra central de Xaquín Lorenzo, adaptado a un montaje que recuerda la galería cultural (Cuisenier y Tricornot, 1987) del Musée des Arts e Traditions Populaires de Paris. El MPG, siempre deficitario en recursos y dependiente de las administraciones mayores y de otros patrocinadores para su funcionamiento, goza de una fuerte masa crítica de patronos y socios pertenecientes a la Universidad y a otros museos, varios de ellos investigadores de las ciencias sociales, entre ellas la antropología y la historia. Ello ha posibilitado y espoleado su evolución reflejada en la renovación de varias salas y en el montaje de otras nuevas centradas ya en los aspectos sociales y en el universo simbólico de la familia y el género, la religiosidad y la fiesta. 


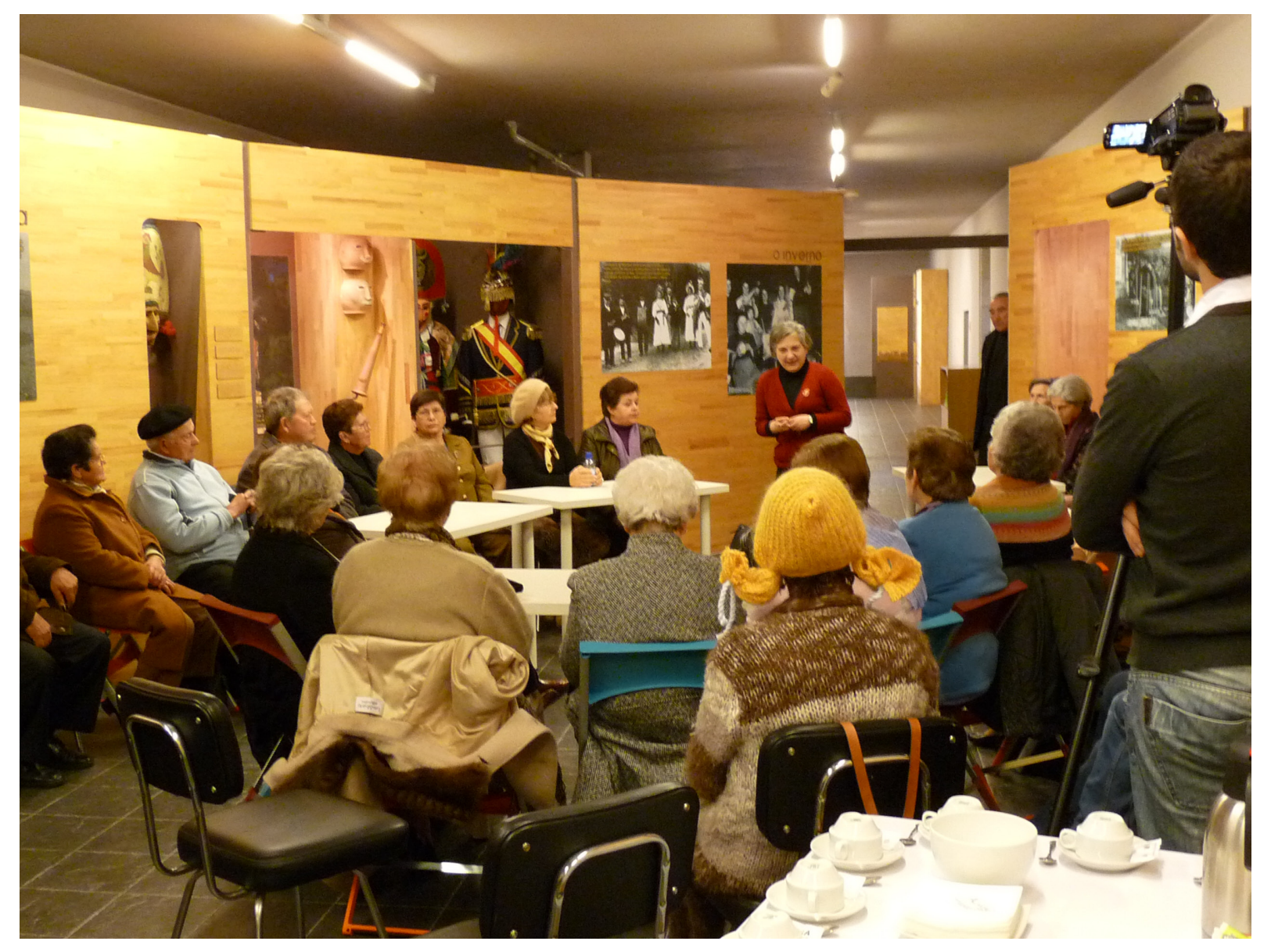

Foto 3. Museo do Pobo Galego (Santiago de Compostela). Cafés de la Memoria: Talleres de expresión oral con gente mayor

Con nuevos enfoques museográficos, el museo focaliza todavía su mirada hacia el mundo rural en sus expresiones agro-campesinas y marineras, aunque mediante exposiciones temporales se ha abierto el foco a otros ámbitos como la industria conservera o a cuestiones decisivas en la coyuntura actual de Galicia como la ganadería y sus especializaciones cárnica y lechera. El museo ha desarrollado una intensa actividad editorial con monografías especializadas y de divulgación y creado a través de sus socios una revista aparecida en 2005 con el nombre de ADRA, cuya gestión y coordinación cedió el patronato del MPG a sus socios (Braña, 2008:156-158). También ha puesto en marcha el patronato del MPG el IEI (Instituto de Estudos das Identidades) encargado de organizar encuentros y debates sobre temas candentes y el APOI (Arquivo do Patrimonio Oral da Identidade), constituido por un fondo único en Galicia de música popular, producto de un trabajo de campo de más de treinta años a través de distintas comarcas del país. El MPG, creado en 1976, se ha implicado en la tarea de analizar y mostrar los rasgos identificadores del pueblo gallego, pasando de las imágenes ruralizadas 
de actividades y oficios de sus primeros años a la necesidad de reflejar en sus salas y programas de difusión otras imágenes alternativas a la etnografía del pasado, huellas pretéritas vistas como heteroimágenes por muchos miembros de la sociedad urbana. Los nuevos marcadores culturales muestran la inserción de esta sociedad en un concierto glocal (Robertson, 1997:28ss), que se debate entre la homogeneización modernizadora y la heterogeneización localizadora (Featherstone y Lash, 1997:4-5) y en el que se dan cita, para ser culturalmente reformulados, los nuevos parámetros de las identidades gallegas. El museo asume en su propia historia institucional el hecho diferencial de Galicia, sin distanciarse de la comunidad política imaginada (González Reboredo, 1999a), promoviendo una actitud implicada en su tarea documental, divulgadora e investigadora. La serie de simposios titulada O Feito Diferencial Galego, iniciada en 1998, así como los libros de Actas editados, examinan desde la perspectiva actual el repertorio identitario gallego a través de la Historia, la Música, la Antropología, la Geografía y el Derecho. Sus estudios, ponencias y debates ha supuesto un desafío para la reorientación museológica del Museo y un estímulo para la constitución posterior del IEI, encargado de organizar los foros y debates que sobre la identidad, el territorio y la demografía se han celebrado.

Entre 1970 y 1985 se formaron otros museos, que consideraban obligado incorporar lo etnográfico a su programación. Su planteamiento conceptual no difiere de las musealizaciones posteriores, aunque sí su compromiso para la formación de sus colecciones, documentándolas y difundiéndolas con dignidad museográfica. El Museo Liste de Oseira (Cea, Ourense) fue el pionero y su creador una persona convencida de la necesidad de recuperar las pisadas del campesinado, de su repertorio técnico y del equipamiento utilizado por las familias y comunidades agroganaderas. Su trayectoria fue compleja y los apoyos recibidos para montar una exposición estable -capaz de albergar un número superior a las 6.000 piezas procedentes de diferentes comarcas de Galiciaepisódicos y deficitarios. En el año 2000 el Ayuntamiento de Vigo le cedió una sede a la que se trasladó un $25-30 \%$ de la colección original. La museografía del nuevo centro de la Fundación Liste-Museo Etnográfico de Vigo mudó radicalmente y su creador y colaboradores organizaron una exposición estable caracterizada por un minimalismo textual y por la adecuación sugerente de algunas salas. Su propuesta era y es la de organizar la visita como un taller en el que el guía establece una relación dialógica con el visitante. El complejo cultural que asoma tras la exposición es netamente rural y mayoritariamente ligado a materiales preindustriales. Asoma la Galicia agraria pura y dura, con escasísimas concesiones a los equipamientos industriales. Su ubicación en la mayor ciudad de Galicia, cuyos marcadores identitarios responden a una aglomeración urbana consecuencia de una industrialización secular, favorece que su actitud ante los visitantes, particularmente los más jóvenes, actúe como un contrapunto donde los significados de lo musealizado y los propios de la vida cotidiana de los visitantes son divergentes. Este museo está desenvolviendo una tarea muy rica, antropológicamente hablando, al hacer transitables 
identidades que, desconociéndose en el tiempo y en el espacio, se entrecruzan bajo la experiencia dialogada de la visita.

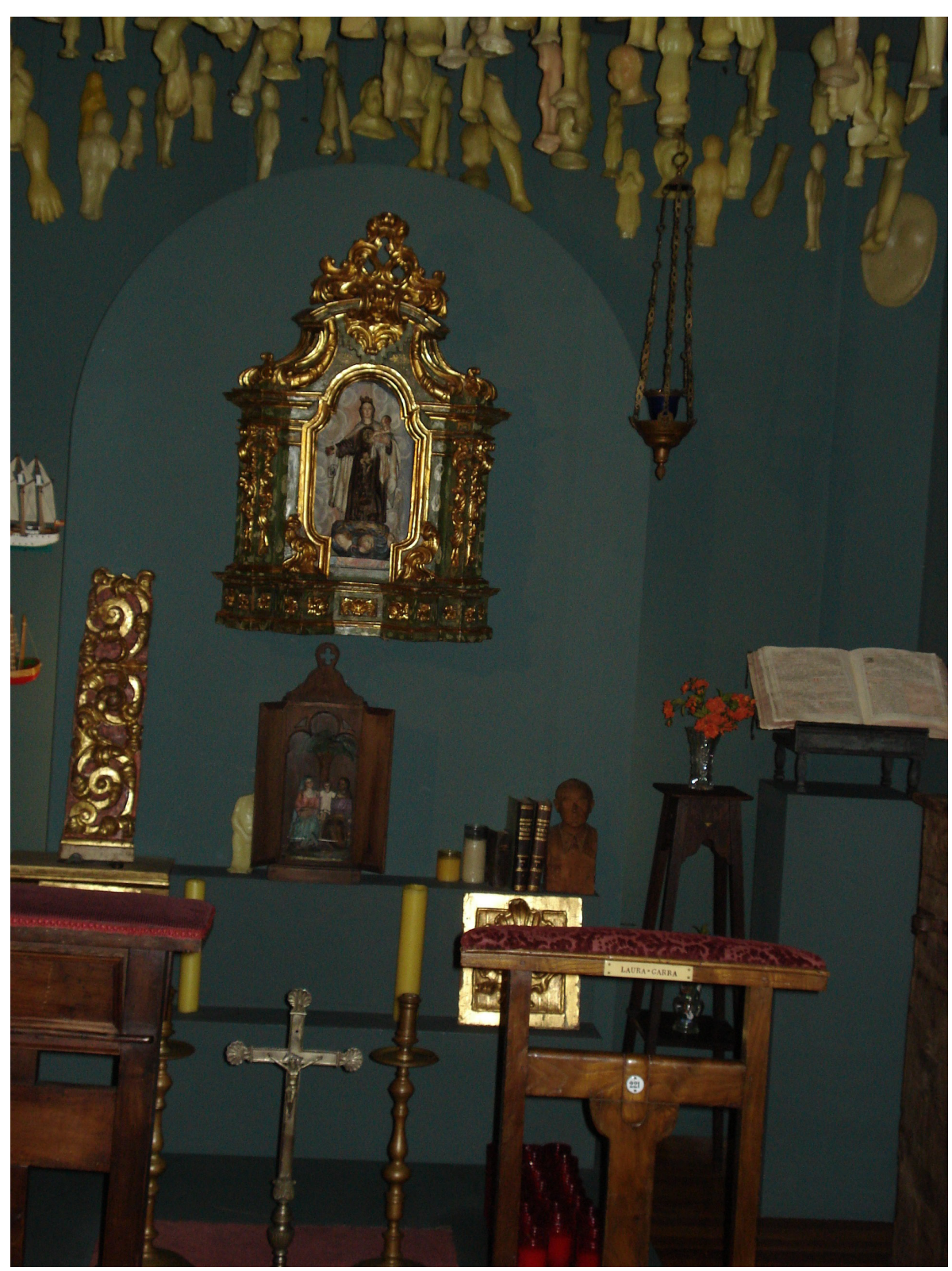

Foto 4. Fundación Museo Liste de Vigo. La religiosidad

La acción cultural de asociaciones locales y vecinales con enfoques muy dinamizadores la encontramos en ejemplos como el de Ponte do Porto (Camariñas, A Coruña) y el de la Terra Cha lucense, donde un Museo Etnográfico Veciñal y una colección promovida por "Amigos da Feira" han activado participativamente sus recursos patrimoniales para incorporarlos a sus memorias (Pereiro y Vilar, 2002:9-10)

Otros dos casos de interés son el Museo Comarcal de A Fonsagrada creado en 1984 en esta villa de la montaña oriental de Lugo, y el Museo da Terra de Melide, formado 
en esta emblemática villa del sudeste de la provincia coruñesa en 1982. Ambos nacen de la iniciativa de asociaciones culturales y ambos miran al MPG como inspiración y modelo. El primero centra su museografía en la etnografía rural de aquella comarca de montaña y el segundo combina una sección arqueológica con otra etnográfica en la que los fondos proceden igualmente de su comarca. Aunque siguen anclados en un enfoque ruralista y pasadista, derivado de la influencia confesada del MPG de la primera fase y de los presupuestos conceptuales, fuertemente interiorizados, de los etnógrafos clásicos del SEG, la tarea acometida y la continuidad que han logrado para sus museos son, hoy por hoy, ejemplares en Galicia. Después de lograr una sede física estable y de recorrer un camino con muchas discontinuidades en los apoyos, su interés radica en el compromiso de un trabajo voluntario que asumen sus fundadores y sus respectivas asociaciones (Chaumier, 2003:25ss), consiguiendo lo que muy pocos museos de municipios rurales han conseguido, que es tener un horario estable de apertura acompañado de numerosas actividades didácticas para sus visitantes. El de A Fonsagrada ha incorporado a sus salas, buscando la relación entre la producción de utensilios y sus materiales, un conjunto de piezas escultóricas realizadas por artistas significados con los mismos materiales de los objetos a los que acompañan, mostrando la relación arte-artesanía y la mirada que echa un escultor a los instrumentos "a los que dio forma" un artesano.

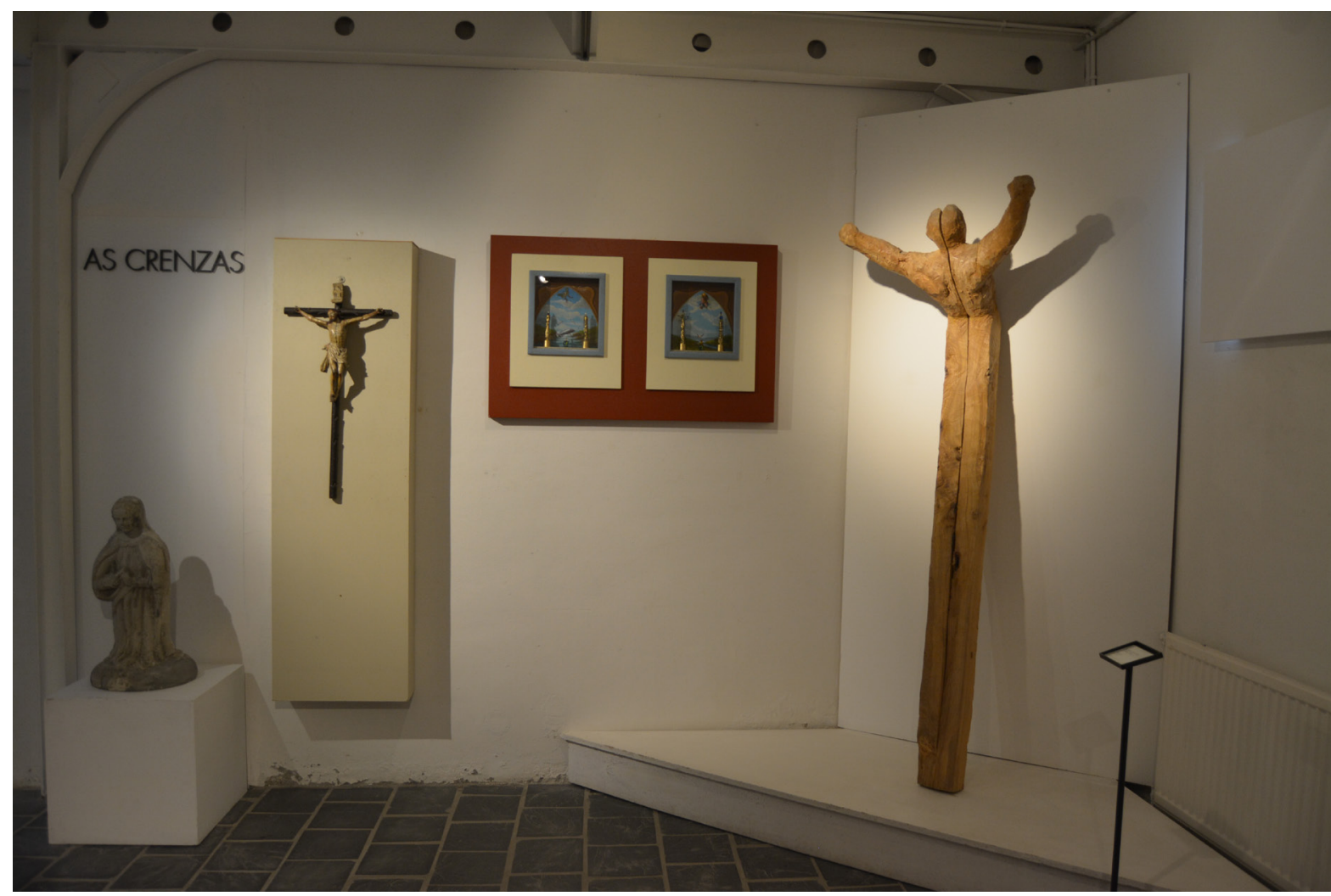

Foto 5. Museo de A Fonsagrada (Lugo). Las creencias: conjunción de arte contemporáneo e imaginería popular 
En la red municipal los museos que incluyen una sección de etnografía integrada en una trayectoria musealizadora mínimamente estable son muy pocos, siendo destacable en unos cuantos casos su continuidad y haber dotado de personal propio al museo. Dos de ellos son pioneros en la museística municipal -exceptuadas las siete ciudades mayores-, ya que tanto el Museo de As Mariñas de Betanzos (A Coruña) como el Municipal de Ponteareas (Pontevedra) vieron la luz respectivamente en 1983 y 1985. Los dos tienen secciones etnográficas, cuyo espejo refleja igualmente lo rural y/o artesanal, y el de Ponteareas se ha focalizado hacia la artesanía textil con la colaboración de una persona muy ligada a esta actividad y a los nuevos practicantes de este oficio.

En la red pública y operando, simultáneamente, como complemento y réplica al MPG, el Museo Etnolóxico (Ribadavia-Ourense) ha optado por distanciarse de los enfoques etnográficos habituales para centrar su tarea museográfica sobre la combinación del trinomio objetos-palabras-imágenes, abriéndole desde 1998/2000 un cauce a la fotografía y a la imagen y buscando un diálogo con la fuente oral obtenida por el trabajo de campo de colaboradores del museo. La relativización del objeto como protagonista de sí mismo posibilita un juego de enlaces que facilita su operatividad hermenéutica (Padiglione, 2008). Paralelamente, desde 2005, se ha puesto en marcha el proyecto Museo Aberto con tres programas orientados a trabajar con los reclusos del Centro Penitenciario de Ourense, con los enfermos de Alzheimer de la capital y con los discapacitados psíquicos atendidos por Cruz Roja (Braña, Iglesias y Sierra, 2012). Confrontar el patrimonio con espacios alternativos e identidades en conflicto (Cameron y Kelly, 2010) posibilita el cruce de identidades y la disparidad de percepciones de los actores convocados y muestra la plasticidad potencial de las colecciones de un museo y su subordinación a la diversidad de miradas de los sujetos, que elaboran, deshacen y rehacen sus múltiples significados.

\section{CONCLUSIÓN}

Hemos sugerido una mirada alternativa hacia los museos y colecciones de artes plásticas, planteado las condiciones y posibilidades de desarrollo de la museología industrial, susceptible de abrir en Galicia su angular, y examinado y debatido las grandes carencias y atrancos del museo etnográfico que, salvo excepciones, se asemeja cada día más a un museo arqueológico sin paralelos ni estratigrafía. Hemos hablado de la identidad y su manejo, señalando que nuestros museos, al fijar y fosilizar ciertas estampas identitarias, impiden ver los cambios de las identidades que se mueven tejiendo sus asociaciones y disociaciones y ocultando las alteridades que, construidas desde dentro (urbanización, industrialización, terciarización) o incorporadas desde fuera (ideas, alternativas, 
propuestas), articulan nuevas identidades o, lo más habitual y lo más "glocal", fuerzan dialécticamente la tradición, que no es el pasado sino el tránsito y la renovación.

Muchas patrimonializaciones y musealizaciones en los municipios rurales, al producir una iconografía vulgarizada de lo etnográfico y actuar sobre los bienes seleccionados, olvidando que forman parte de las culturas del trabajo y obviando sus condicionamientos sociales -posiciones de clase, género y edad-, han situado los objetos “etnográficos" en un tiempo monumental (Santos, 1997) ocultando o haciendo nebuloso el tiempo social (Herzfeld, 1991). Para cerrar el círculo, las fijaciones institucionales amparadas en su normativa legal esclerotizan estas imágenes (Agudo, 2006; Pereiro, 2012) reduciendo museos y patrimonios culturales a estampas identitarias.

Los elementos a los que otorgamos el estatuto de bienes culturales, aunque pertenezcan al pasado y al repertorio patrimonial agro-campesino o a formas protoindustriales pretéritas, pueden ser objeto de activaciones patrimoniales cuya actualidad reside en que se incorporan a las experiencias socioculturales del presente (Fernández de Paz, 1997) que las reinterpreta bajo estrategias de configuración múltiple en las que se conjugan su visión y su aprovechamiento como emblemas culturales o tesoros, como espacios para la reflexión cultural, como marcos identitarios y como recursos (Fernández de Paz, 2002). Esta última utilización, que desde la expectativa turística es la que interesa mayoritariamente a los agentes políticos locales y a los de las administraciones mayores que los tutelan, puede integrase como factor combinado en otras prácticas orientadas a abrir canales de desarrollo social en los que el factor identitario opera como dispositivo de cohesión y ensamblaje de los ritmos, intereses y proyectos de ciertas comunidades. En Galicia las bien conocidas experiencias ourensanas de Allariz -con su Parque Etnográfico del Rio Arnoia- y Vilar de Santos (Museo de A Limia), o la del Museo Etnográfico de A Capela (A Coruña), además de las analizadas por Pereiro y Vilar (2002), ejemplifican rutas patrimonializadoras y musealizadoras asociadas a la participación de la comunidad local, sin renunciar a la acogida del visitante foráneo y del turista. En algunos casos el planteamiento museológico ha sido superado por un exceso de actividad cultural y patrimonializadora (Allariz), en otros casos la falta de recursos humanos ha estancado parcialmente aspectos sustantivos de la experiencia museal -paralización del taller textil en el Museo de A Limia (Braña, Mariño y Mouriño, 1999)- y en otros la formalización y consolidación institucional del museo al margen de su marco inicial debilitó aspectos muy fecundos del proyecto como acontece con el Museo de A Capela, nacido de una experiencia escolar muy rica en vivencias y significados (Sierra, 2013). 


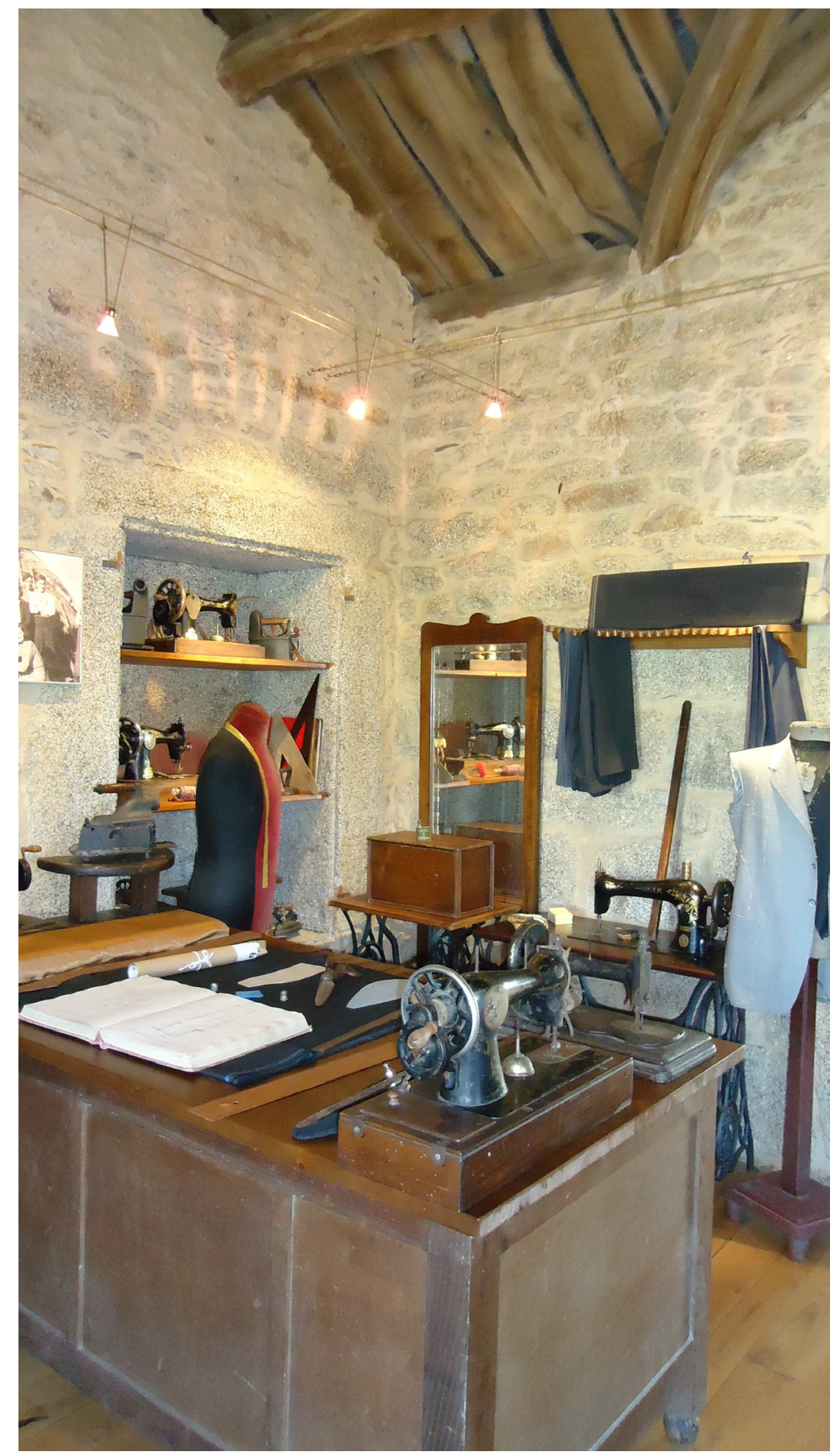

Foto 6. Museo de A Capela (A Coruña). Taller de sastrería

Tras estas trazos se dibuja el mapa museal de Galicia, cuyos rasgos, singularidades y contradicciones nos permiten una aproximación a lo existente y una problematización de lo posible y de lo necesario o, cuando menos, de lo que resulta viable para conferir al museo un papel normalizado en su apuesta para dar testimonio de la cultura de unas comunidades y de sus territorios. 


\section{REFERENCIAS BIBLIOGRÁFICAS}

Agudo Torrico, Juan (2006) "Patrimónios e discursos identitários". En E. Peralta y M. Anico (orgs.) Patrimónios e Identidades. Ficções Contemporâneas. Oeiras: Celta Editora, pp. $21-34$

Albert, Bruce (1995) “Anthropologie appliquée ou 'anthropologie impliquée??". En J.-F. Baré (dir.) Les applications de lanthropologie. Un essai de réflexion collective depuis la France. Paris: Karthala, pp. 87-118.

Barriocanal Lopez, Yolanda y Fariña Busto, Francisco (1989) El antiguo museo de pinturas de Ourense (1845-1852). Vigo: Boletín Auriense. Anexos 13.

Barroso, Eliane y Vaillant, Emilia (1993) Musées et Sociétés. Actes du Colloque de Mulhouse-Urgeschein. Paris.

Beck, Ulrich (1999) ¿Qué es la globalización? Falacias del globalismo, respuestas a la globalización. Barcelona: Paidós.

Blanco Desar. Manuel (2014) Galicia: un pobo con futuro? O noso devalo demográfico. Vigo: Edicións Xerais de Galicia-IEI/Museo do Pobo Galego.

Bouhier, A. (1979) La Galice. Essai géographique d'analyse et d'interpretation d'un vieux complexe agraire. La Roche-Sur-Yon, 2 vols.

Bourdieu, Pierre (1997) Razones prácticas. Sobre la teoría de la acción. Barcelona: Editorial Anagrama.

Braña Rey, Fátima (1997) "O Museo Provincial do Mar”. En Actas do III Congreso de Historia da Antropoloxía e Antropoloxía Aplicada II. Pontevedra: IPSEG-CSIC, pp. 135144

Braña, Fátima, Mariño, Marian y Mouriño, Eva (1999) “Trama y urdimbre. Género y gestión patrimonial en Vilar de Santos". En E. Fernández de Paz y J. Agudo (coords.) Patrimonio cultural y museología. Significados y contenidos. A Coruña: FAAEEAGANTRO, pp. 81-88.

Braña Rey, Fátima (2008) O Museo do Pobo Galego. Contedor de valores. A Coruña: Fundación Antonio Fraguas-MPG

Braña, Fátima; Iglesias, Ma Pilar y Sierra, Xosé C. (2013) “El trabajo a partir del patrimonio cultural: desde el constructo social a la interpretación de la vida cotidiana". En T. Vicente y J. Bodí (eds.) Geopolíticas patrimoniales: de culturas, naturalezas e inmaterialidades. Una mirada etnográfica. Valencia: Germania, pp. 1-14.

Buron Díaz, Manuel (2012) "Los museos comunitarios mexicanos en el proceso de renovación museológica”, Revista de Indias LXXII (254), pp. 177-212. 
Calo Lourido, Francisco (1984) "The Seafaring Fishing Family as an Economy Community in Porto do Son, Galicia, Spain”. En The Fishing Culture of the World. Budapest: Akademiai Kiadó.

Calo Lourido, Francisco (1998) "Peculiaridades da sociedade mariñeira". En X.M. González Reboredo (Coord.) Galicia. Antropoloxía. Aresanía. Sociedade. A Coruña: Hécules, pp. 201-231.

Calo Lourido, Francisco (2014) "A cultura da terra e a cultura do mar". PORTUGALIA XXXV, pp. 151-163.

Camarena, Cuauhtémoc y Morales, Teresa (2009) "El museo comunitario: un espacio para el ejercicio del poder comunal”, en I. Arrieta (ed.) Activaciones patrimoniales e iniciativas museísticas: ¿por quién? y ¿para qué?”. Bilbao: Universidad del País Vasco/ Euskal Herriko Unibertsitatea, pp. 115-128.

Cameron, Fiona y Kelly, Linda (2010) Hot Topics. Public Culture, Museums. Cambridge: Cambridge Scholars Publishing.

Cardesin Díaz, José María (1999) “Mercado, Estado e Aldea: a construción do campesiñado en Galicia”. En M. Gondar (coord.) O feito Diferencial Galego.III. Antropoloxía III (1) pp. 131-153.

Cardesin Díaz, José María (1999a) "Redes flexibles y redes rígidas: urbanización, producción y transporte en la Galicia litoral”. En J.M. Cardesín y B. Ruiz (introd.) Antropología hoy: técnicas, teorías y tácticas, AREAS. Revista de Ciencias Sociales, 19. pp. 117-135.

Cardesin Díaz, José María (2005) “A memoria esquecida da Galicia rural”. En G. Quiroga y X.C. Sierra (coords.) Imaxes de Galicia: Fotografía Etnográfica (Homenaxe a Xaquín Lorenzo). Santiago de Compostela: Xunta de Galicia, pp. 39-42.

Carmona Badía, Joám (1990) El atraso industrial de Galicia. Auge y liquidación de las manufacturas textiles (1750-1900). Barcelona: Ariel.

Carmona Badía, Joám y NADAL, Jordi (2005) El empeño industrial de Galicia. 250 años de historia, 1750-2000. A Coruña: Fundación P. Barrié de la Maza.

Castells, Manuel (1999) La Era de la Información. Economía, Sociedad, Cultura. Vol. 1: La sociedad Red. Madrid: Alianza.

Castro, Xosé Antón (1992), Arte y nacionalismo. La vanguardia histórica gallega (19251936), Sada-A Coruña: Edicións do Castro.

Castro Borrego, Fernando (1992) "A escultura galega hoxe. Unha visión dende o Atlántico". En Galicia no Tempo 1991. Conferencias/Outros estudios. Santiago de Compostela: Consellería de Cultura e Xuventude, pp. 326-333. 
Cátedra, María (1998) "Las desventuras de un edificio singular: la Fábrica de Harinas de Ávila”. En P. Castro, X. Pereiro y P.M. Santos (coords.) Cultura e Arquitectura: Ilusións antropolóxicas no espacio construído. Santiago de Compostela: Edicións Lea, pp. 25-66.

Chamoso Lamas, Manuel (1974) "La creación de museos de artes y costumbres populares en Galicia”. En Actas del II Congreso Nacional de Artes y Costumbres Populares. Zaragoza: Institución Fernando el Católico, pp. 33-41.

Chaumier, Serge (2003) Des musées en quête d'identité. Écomusée versus technomusée. Paris: L'Harmattan.

Clair, Jean (1992) "Les origines de la notion d'ecomusée" [1976] Vagues- 1. Une anthologie de la Nouvelle muséologie. Mâcon: W/M.N.E.S., pp. 433-439.

Clifford, James (1995) Dilemas de la cultura. Antropología, literatura y arte en la perspectiva postmoderna. Barcelona: Gedisa.

Collet, Isabelle (1987) "Les premiers musées d’ethnographie régionale en France". En Muséologie et Ethnologie. Paris: Réunion des musées nationaux, pp. 68-99.

Cuisenier, Jean y Tricornot, Marie Chantal (1987) Musée National des Arts et Traditions Populaires. Guide. París: Réunion des musées nationaux.

Desvallées, André (1994) “Les musées d'ethnographie, ont-ils encore un sens?". Anales del Museo Nacional de Antropología 1, pp. 51-84.

Duclós, Jean-Claude (1997) “Le Muséee aujourd'hui. La pertinence des expositions”. En D. Grange y D. Poulot (dir.) L'Esprit des lieux. Le patrimoine et la cité. Grenoble: Presses Universitaires, pp. 263-270.

Durán, José Antonio (1978) "O problema agrario. I. Outro proceso de cambio por derrubamento" En J.A. Durán, Galicia. Realidade económica e conflicto social. A Coruña: Banco de Bilbao-Servicio de Estudios, pp. 17-72 (obra censurada por el editor y retirada del mercado).

Esteva Fabregat, Claudio (1969) "La etnología española y sus problemas". En Actas del I Congreso Nacional de Artes y Costumbres Populares, 1968. Zaragoza: Institución Fernando el Católico, pp. 1-40.

Featherstone, Mike y LASH, Scott (1997) "Globalization, Modernity and the Spatialization of Social Theory: An Introduction". En M. Featherstone, S. Lash y R. Robertson (eds.) Global Modernities. London-Thousand Oaks-New Delhi: Sage Publications Ltd., pp. 1-24. Fernández de Paz, Esther (1997) "El estudio de la cultura en los museos etnográficos". Boletín del Instituto Andaluz del Patrimonio Histórico 18, pp.109-118. 
Fernández de Paz, Esther (1996) "El patrimonio etnológico en la práctica antropológica: de la iniciativa aislada al proteccionismo oficial". En E. Aguilar (coord.) De la construcción histórica a la práctica de la antropología en España. Zaragoza: FAAEE-Instituto Aragonés de Antropología, pp. 205-217.

Fernández de Paz, Esther (2002) "El concepto de patrimonio cultural desde la perspectiva de la antropología”. En J.M. Iglesias (ed.) Cursos sobre el patrimonio histórico 6. Santander: Universidad de Cantabria-Ayuntamiento de Reinosa, pp. 39-52.

Fernández de Rota, José Antonio (1992) "La antropología gallega a debate". Anales de la Fundación Joaquín Costa 9, pp. 123-145.

Fernández Prieto, Lourenzo (1992) Labregos con ciencia. Estado, sociedade e innovación tecnolóxica na agricultura galega, 1850-1939. Vigo: Xerais de Galicia.

Fernández Prieto, L. y otros (1993) Estudio socioeconómico do Ribeiro. Santiago de Compostela: I.D.E.G.A.-USC (inédito).

García Canclini, Néstor (2003) “Un museo para la globalización”. Otra Parte 1, primaveraverano (http://www.revistaotraparte.com/no-1-primavera-verano)

García Canclini, Néstor (2004) Diferentes, desiguales y desconectados. Mapas de la interculturalidad. Barcelona: Gedisa.

García Martínez, Carlos; PERNAS, Herminia y F. CERVIÑO, Ma Xosé(2006) A Gandaría. Tesouro de Galicia. A Coruña: Museo do Pobo Galego-Ternera Gallega.

González Reboredo, Xosé Manuel (1996) "Notas para una historia de la antropología en Galicia”. En Identidad y fronteras culturales: Antropología y museística. Badajoz: Psicoex, pp. 707-718.

González Reboredo, Xosé Manuel (1999) “Aproximación a la identidad del emigrante gallego”. En X.M. González (coord.) Proyecto Galicia. Antropología XXVI. A Coruña: Hércules, pp. 492-521.

González Reboredo, Xosé Manuel (1999a) "Etnicidad y nacionalismo. El caso de Galicia". En C. Stallaert (ed.) Hechos diferenciales y convivencias interétnicas en España. Revista Hispánica de los Países Bajos 16-diciembre, pp. 55-68.

Gouveia, Henrique C. (1985) "Acerca do conceito e evolução dos Museus Regionais portugueses desde finas do s. XIX ao regime do Estado Novo". Bibliotecas, Arquvos e Museus 1, pp. 152-175.

Guillaume, Marc (1980) La politique du patrimoine. Paris: Galilée.

Hannerz, Ulf (1998) Conexiones transnacionales. Cultura, gente, lugares. Madrid: Cátedra. 
Herrero, Nieves (1999) "A modernización rural. Unha concreción etnográfica”. En M. Gondar (coord.) O Feito diferencial galego III Antropoloxía 2. Santiago de Compostela: Museo do Pobo Galego, pp. 163-179.

Herzfeld, Michael (1991) A Place in History: social and monumental time in a cretan town. Princeton: Princeton University Press.

Hubert, François (1989) “Dossier Ecomusée. Historique des écomusées”. En La Muséologie selon Goerge Henri Rivière. Paris: Dunod, pp. 146-154.

Iniesta i gonzález, M. (1994): Els gabinets del món. Antropología, museus i museologies. Lleida: Pagès.

Iturra, Raúl (1988) Antropología económica de la Galicia rural. Santiago de Compostela: Xunta de Galicia.

Iturra, Raúl (1999) “Campesiñado e identidade”. En M. Gondar (coord.) O Feito diferencial galego III Antropoloxía 1. Santiago de Compostela: Museo do Pobo Galego, pp. 97-104.

Jamin, Jean (1998) “Faut-il brûler les musées d’ethnographie?”. Gradhiv, 24, pp. 65-69.

Korff, G. (1996) "Remarques sur les programmes de recherche dans les musées dethnologie". En Rencontres européennes des musées d’ethnographie 1993. París: Musée National des Arts et Traditions Populaires-École du Louvre, pp. 121-126.

Lemonnier, Pierre (2010) "L'Étude des systèmes techniques, une urgence en technologie culturelle”. Techniques \& Culture 54-55 (1), pp. 46-67.

Lenclud, G. (1995) "Le grand partage ou la tentation ethnologique". En G. Althabe, D. Fabre y G. Lenclud (dirs.) Vers une ethnologie du présent. París: Éditions de la Maison des sciences de l'homme.

Limón Delgado, Antonio (1983) "Notas sobre museología etnográfica”. En Actas del IV Congreso Nacional de Artes y Costumbres Populares. Zaragoza: s.p.

Lois González, Rubén y Piñeira Mantiñán, Ma José (1998) “Os espacios construidos en Galicia: persistencias da cultura labrega despois do proceso de urbanización”. En Seixas, Pereiro y Santos (coords.) Cultura, Arquitectura: Incursións antropolóxicas no espacio construido. Santiago: Lea., pp. 189-211.

Lomnitz, Larissa A. (2003) "Globalización, economía informal y redes sociales". En J.L. García y A. Barañano (coords.) Culturas en contacto. Encuentros y desencuentros. Madrid: $\mathrm{M}^{\circ}$ de Educación, Cultura y Deporte, pp. 129-146.

López, Aurora; López Prado, Covadonga y Lemos, Beatriz (1993) Censo de Museos de Galicia. Normas para o inventario. Lugo: Consellería de Cultura. 
López Iglesias, Edelmiro (1997) "Crise da agricultura tradicional e formación do agricultor. As mudanzas experimentadas polo agro galego na segunda metade do s. XX". En Galicia fai dous mil anos. O feito diferencial galego I. Historia 2. Santiago de Compostela: Museo do Pobo Galego, pp. 219-223.

López Iglesias, Edelmiro (1998) "O sector agrario galego na Unión Europea: balance da súa dinámica na última década”. Análise Empresarial. Revista Galega de Economía e Ciencias Sociais 27, pp. 3-15.

López Vázquez, José Manuel (1990) "Panorama das artes na idade contemporánea”. En Galicia no Tempo. Catálogo de Exposición. Santiago de Compostela: Consellería de Cultura e Xuventude, pp. 379-405.

López Vázquez, José Manuel (2000) “O debuxo de Castelao”. En Castelao. Exposición 50 aniversario. Castelao e a Arte. A Coruña: Fundación Caixa Galicia-Fundación CastelaoMuseo de Pontevedra, pp.23-38.

López Vázquez, José Manuel (2006) "O primitivismo da arte galega ata Luis Seoane: na procura da identidade". En Do primitivo da arte galega ata Luis Seoane. Procesos de creación artística e de identidade nacional. A Coruña: Fundación Luis Seoane, pp. 33-193. Mack, John (2007) "Les métamorphoses de la qualification". En Bruno Latour (dir.) Le dialogue des cultures. Actes des Rencontres inaugurales du Musée du Quai Branly. Paris: Musée du Quai Branly, pp. 21-68.

Mairesse, François (2013) "Logique du don et biens comuns: réinventer le musée". En I. Arrieta (ed.) Reinventando los Museos. Bilbao: Universidad del País Vasco/Euskal Herriko Unibertsitatea, pp. 45-64.

Mato, Alfonso (2001) O Seminario de Estudos Galegos. Sada: Edicións do Castro.

Morel, Alain y Vallerant, Jacques (1984) "Anthropologie industrielle: recherche en develppement". Terrain 2, pp. 3-4.

Moreno, Isidoro (1999) "Globalización, ideologías sobre el trabajo y culturas del trabajo". En B. Ruiz y J.M. Cardesín (eds.) Antropología hoy: teorías, técnicas y tácticas. AREAS. Revista de Ciencias Sociales 19, pp. 18-34.

Nieto Gallo, Gratiniano (1969) "Museos de Artes y Costumbres Populares". Actas del I Congreso Nacional de Artes y Tradiciones Populares. Zaragoza: Institución Fernando el Católico, pp. 67-84.

Nuñez Seixas, Xosé Manuel (1998) Emigrantes, caciques e indianos. O influxo sociopolítico da emigración transoceánica en Galicia (1900-1930). Vigo: Edicións Xerais de Galicia.

Padiglione, Vicenzo (1995) “Per una centralità delletnografia nei musei”. Etnoantropologia 3-4, pp. 238-247. 
Padiglione, Vicenzo (1999) "El efecto marco. Las mediaciones del patrimonio y la competencia antropológica". En E. Aguilar (ed.) Patrimonio Etnológico. Nuevas perspectivas de Estudio. Cuadernos X. Sevilla: IAPH, pp. 212-227.

Padiglione, Vicenzo (2008) "La ordenación de los pequeños museos etnográficos: nuevos horizontes técnicos entre antropología y arte”. En J.L. Alonso, J. Díaz y C. Piñel (dirs.) Teoría y praxis de la museografía etnográfica. Zamora: Museo Etnográfico de Castilla y León, pp. 203-216.

Pereiro, Xerardo (2001) "Reflexão sobre a antropologia na Galiza de Hoje". Etnográfica V (1), pp. 175-183.

Pereiro, Xerardo (2006) "Património cultural: o casamento entre património e cultura". ADRA-Revista dos sócios do Museu do Povo Galego 2, pp. 23-41.

Pereiro, Xerardo (2008) “A produción sociopolítica do património etno-antropolóxico en Galicia”. En F. Delgado (coord.) III Xornadas sobre a protección do patrimonio cultural. O patrimonio etnográfico. Santiago de Compostela: Xunta de Galicia, pp. 129-141.

Pereiro, Xerardo (2009) “A lexislación do patrimonio etno-antropolóxico na Galiza: unha vision antropolóxica". En X.A. Fidalgo y otros (coords.) Patrimonio Etnográfico Galego II. Ourense: Deputación Provincial, pp. 9-14.

Pereiro, Xerardo (2012) "La concepción del patrimonio etnoantropológico en Galicia: visiones legales y prácticas institucionales". Revista Andaluza de Antropología 2, pp. 2547.

Pereiro, Xerardo y Vilar, Manuel (2002) “Autoimágenes y heteroimágenes en los museos etnográficos gallegos". En E. Fernández de Paz y S. Ventosa (coords.) La imagen del otro en el museo. Barcelona: FAAEE-ICA.

Pérez, Yolanda; Serrano, Nuria y Vilar, Manuel (1997) "El desaparecido museo de Pías en el Balneario de Mondariz". En Actas do III Congreso de Historia da Antropoloxía e da Antropoloxía Aplicada II. Pontevedra: IPSEG-CSIC, pp. 145-167.

Robertson, Roland Scott (1997) "Glocalization: Time-Space and HomogeneityHeterogeneity”. En M. Featherstone, S. Lash y R. Robertson (eds.) Global Modernities. London: Sage, pp, 25-44.

Rodríguez Campos, Xaquín (1991) "La etnografía clásica en Galicia: Ideas y proyectos". En J. Prat, U. Martínez, J. Contreras e I. Moreno, Antropología e los Pueblos de España. Madrid: Taurus, pp. 99-11.

Romero de Tejada, Pilar (1985) "Situación de la Etnología en los museos españoles". Actas $2^{\circ}$ Congreso de Antropología, Madrid, pp. 40-44. 
Ruiz Fernández, Beatriz (1999) "A Galicia externa, Identidade complexa versus identidade simple. O caso das emigrantes retornadas de Vigo e o seu contorno". En M. Gondar (coord.) O Feito diferencial galego III Antropoloxía 1. A Coruña: Museo do Pobo Galego, pp. 277-289.

Santana Talavera, Agustín (1999) "Identidade e turismo rural.¿Un producto diferente para unha demanda similar?” En M. Gondar (coord.) O Feito difrencial galego III Antropoloxía 2. A Coruña: Museo do Pobo Galego, pp. 181-195.

Santana, Agustín y Estévez, Fernando (1996) "Antropología del turismo". En J. Prat y A. Martínez (eds.) Homenaje a Claudio Esteva Fabregat. Barcelona: Ariel, pp. 286-293.

Santos, Margarida (1996) "Entre o local e o global: a cultura como argumento". Arquivos da Memoria 2. Lisboa: Centro de Estudos de Etnologia Portuguesa, pp. 49-56.

Shatanawi, M. (2009) "Contemporary art in ethnographic museums". En H. Belting y A. Buddensieg (eds.) The Global Art World: Audiences, Markets, and Museums, OstfildernRuit: Hatje Cantz, pp. 368-384.

Sierra Rodríguez, Xosé C. (1998) "Conciencia e problemática para a Introdución e o Desenvolvimento das Concepcións da Nova Museoloxía na Galiza. Sutuación e perspectivas". En Ecomuseologia como Forma de Desenvolvimento Integrado. Povoa de Lanhoso: MINOM-Cámara Municipal de Póvoa de Lanhoso, pp. 103-117.

Sierra Rodríguez, Xosé C. (1999) "Experiencias de patrimonialización e musealización. Identidade local en concellos non urbanos." En M. Gondar (coord.) Galicia fai dous mil anos. O Feito Diferencial Galego III. Antropoloxía 2. Santiago de Compostela: Museo do Pobo Galego, pp. 296-327.

Sierra Rodríguez, Xosé C. (2000) "Patrimonio Etnográfico en Galicia. Procesos de patrimonialización en Galicia”. En X.M. González (coord.) Proyecto Galicia. Antropología XXIX. A Coruña: Hércules, pp. 379-471.

Sierra Rodríguez, Xosé C. (2003) "Museos e desenvolvemento. Experiencias e itinerarios en Galicia”. En Museos: construindo a comunidade. Santiago de Compostela: Consello Galego de Museos, pp. 211-246.

Sierra Rodríguez, Xosé C. (2013) "El museo etnográfico: su prolongada adaptación a la crisis. Experiencias en Galicia”. En I. Arrieta (ed.) Reinventando los Museos. Bilbao: Universidad del País Vasco/Euskal Herriko Unibertsitatea, pp. 107-146.

Sigaut, François (2010) “Retour sur 'La formule de Mauss"'. Techniques \& Culture 54-55 (1), pp. 354-367. 
Sobrino Manzanares, $M^{a}$ Luisa (1992) "A escultura galega hoxe. Do obxecto á idea". En Galicia no Tempo 1991. Conferencias/Outros estudios. Santiago de Compostela: Consellería de Cultura e Xuventude, pp. 335-347.

Soeiro, Teresa (1997) "A Etnografía nas colecções dos museus do distrito do Porto". Actas do III Congreso de Historia da Antropoloxía e Antropoloxía Aplicada. Santiago, pp. 247268.

Soutelo Vázquez, Raúl (1998) "Algunas estrategias reproductivas de las familias campesinas en la Galicia rural. Los grupos domésticos de 'caseiros' en Ourense, 18801960". Sociología del Trabajo 33, pp. 131-155.

Soutelo Vázquez, Raúl (1997) “Memoria oral e historia rural. A aportación dos documentos persoais no estudio interdisciplinar das transformacións económicas e sociais na Galicia campesiña". Semata. Ciencias sociais e Humanidades 9, pp. 343-370.

Varine-Bohan, Hugues de (1992) "L' écomusée" [1978]. Vagues-1. Une anthologie de la Nouvelle muséologie. Mâcon: W/M.N.E.S., pp. 446-487.

Vázquez Varela, José Manuel (2001) "Frei Rosendo Salvado como etnólogo". En O bispo dos sen alma. Santiago de Compostela: Consello da Cultura Galega, pp. 67-73.

Viatte, Germain (2007) "Art moderne, art traditionnel, art contemporain". En Bruno Latour (dir.) Le dialogue des cultures. Actes des Rencontres inaugurales du Musée du Quai Branly. Paris: Musée du Quai Branly, pp. 69-96.

Vence, Xavier (2011) Crise e radicalización neoliberal. As alternativas silenciadas. A Coruña: Laiovento. 